\title{
Education Viruses That Agonizing Education Systems Components
}

\author{
İsmail Gelen ${ }^{1, *}$ \\ ${ }^{1}$ Department of Educational Science, Ondokuz Mayıs University, Samsun, Turkey \\ *Correspondence: Department of Educational Sciences, Education Faculty, Ondokuz Mays University, 55200 \\ Samsun, Turkey. E-mail: ismailgelen@omu.edu.tr. ORCID ID: https://orcid.org/0000-0001-6669-8702
}

Received: September 8, 2020

Accepted: December 4, 2020 Online Published: December 20, 2020

doi:10.5430/wje.v10n6p97

URL: https://doi.org/10.5430/wje.v10n6p97

\begin{abstract}
The purpose of the research is to define the factors that negatively affect education and learning process. Descriptive content analysis, one of the non-interactive qualitative research designs, was used to analyze the data. The analyses were conducted in six stages. First, aim, subject, and research questions were determined. Literature review was done according to the inclusion and exclusion criteria, the literature was read, the literature tags were created in the form of a table, the codes, categories, themes were created inductively according to the descriptive content analysis, and finally, analysis, association, interpretation, signification, and reporting were made. To this aim, 238 research conducted between 2014 and 2018 were jointly investigated within the framework of determined criteria. Correlation between raters was determined as $\mathrm{rp}=0.94$.

According to the obtained results, variables that negatively affect learning related to technology and media may be indicated as phone, tablet, computer, game, internet, cartoons, social media, television, and TV series. Private teaching institutions and central examinations that negatively affect teaching are among the variables related to exams. Negative and disruptive factors arising from the school, education system, and educational practices; assignments, disconnection from real life, discipline problems, legislation and procedures, teaching practices that do not change or be updated, and a low possibility for failing a class are educational fashions. Addiction related viruses such as drugs, technology addiction, smoking habits affect education negatively. Obesity and excessive consumption culture and unhealthy nutrition problems that are health-related problems are also observed. Violence, swearing, using slang words, peer bullying, moral collapse, noise pollution, and problems stemming from ignoring others are the problems arising from all kinds of school environments.
\end{abstract}

Keywords: education, problem, learning, education systems, student

\section{Introduction}

\subsection{Problem Statements}

Education is a process that includes acquisition of the behaviors such as talent, skill, attitude, and aesthetic sensitivity, especially the national, spiritual, and cultural values into which the individual is born. Education is like a balance with a hundred scales; changing something changes everything, and therefore everything is affected by each other. Education is a process that includes acquisition of the behaviors such as talent, skill, attitude, and aesthetic sensitivity along with the national, spiritual, and cultural values into which the individual is born. (MoNE, 2017, 4). The main purpose of the Turkish education system is to raise individuals with knowledge, skills, and behaviors integrated with our values and competencies (MoNE, 2017,6). Education policies and priorities of the Ministry of National Education are to raise students who have national, moral and universal values; are able to be successful both academically and socially, and respect themselves, their society and different cultures with a high level of awareness; adapt to technological developments, and grow up as happy and healthy individuals who are able and ready to live, happy and healthy individuals (MoNE, 2017, 5).

If we turn to basic values of justice, friendship, honesty, self-control, patience, respect, love, responsibility, patriotism, benevolence (MoNE, 2017, 6) that are available in the curriculum are taught as common compulsory values in all programs in order to reach the affective dimensions of this basic purpose. Moreover, eight key competency frameworks have been identified in the curriculum. These competencies are communication in the mother tongue and foreign languages, mathematical competence and basic competencies in science/technology, 
digital competence, learning to learn, social and citizenship competencies, entrepreneurship as well as taking initiative, cultural awareness and expression (http://mufredat.meb.gov.tr, 29 -05-2018).

In the first place, the factors that prevent the achievement of the competencies specified in the curriculum and basic root values should be determined, and their impact should be minimized with the aim of achieving these general goals in education. Again, education policies and priorities developed to achieve the main goals in the Turkish Education System, and the root values and competencies determined accordingly need to identify the problems that hinder, slow down, disrupt education and to minimize its impacts.

In general, virus is defined as the microbe (biological) causing infectious diseases and a factor (electronic) causing the deterioration in computer programs (TLA, 2008, 2349). Based on this definition, in the present research, factors that cause difficulties in learning-teaching process, hinder learning, deteriorate and fail to function properly, and become ill (educational) are called "educational viruses" in the current research.

It is an unavoidable fact that Covid-19 virus, which is the last of the infectious diseases that emerged in the history of the world such as plague, smallpox, cholera, Spanish flu, Hong Kong flu, Hiv-Aids, SARS, swine influenza, Ebola, Mers, has appeared in China in 2019 continues to profoundly affect education, health, economy, management, communication, defense, technology, law, etc. and the life of the entire world from different perspectives throughout 2020. In fact, the factors cause much more difficulties in the learning-teaching process, hinder learning, deteriorate and incline the fulfillment of its functions sufficiently (educational) for centuries in a perpetually increasing and changing way than the effects of Covid-19. To this end, educational problems that have been constantly on the agenda with literature, environmental observations and media are the starting point of this research along with the studies on educational environments (school and/or class) of the 21 st century, "key concepts" that will shape the education of 21st century, learner and teacher competencies of the 21st century, possible problems in education in the 21 st century and undesired situations in education in the 21st century (Gelen 2017a-b, Gelen 2018).

\subsection{Purpose and Questions of the Study}

The primary purpose of the research is to determine what factors decrease and restrict the learning quality, hinder, negatively affect, disrupt, slow down learning, education and especially learners and make meaningful inferences. To this aim, the main question of the research is; What are the factors that hinder, negatively affect, disrupt, slow down, decrease the quality and restrict learning, education and students? In the study, answers to the following sub-questions were searched under this big question:

- Under the theme of technology and media: How do variables such as phone, tablet, computer, game, internet, cartoons, social media, television, and TV series affect learning, education and students negatively?

- Under the theme of exams: How do central exams and private teaching institutions affect learning, education and students negatively?

- Under the theme of school, education system and educational practices: How do homework, disconnection from real life, discipline problems, legislation and procedures, outdated teaching practices, failing a class, and educational fashion variables affect education and students negatively?

- Under the theme of addiction; How do technology addiction, cigarette-drink-drug addiction variables negatively affect learning, education and students?

- Under the theme of health: How do obesity, over-consumption, unhealthy nutrition variables affect education and students negatively?

- Under the theme of the environment: How do violence, swearing and using slang language, peer bullying, moral collapse, noise pollution, urbanization, ignoring others, and empty talk variables affect education and students negatively?

\section{Method}

Through big data, it is possible to create smart systems to bring together and make sense of disconnected and meaningless data in order to make decisions, plan the future better, and save many things such as time-energy, money, labor. Big data has become a necessity in all areas. Similarly, it has been treasure worthy data hunt, raw material of the information economy, fuel, and the biggest power that can be extracted from the passive data in every area used by insurance companies, economists, weather forecasters, people in healthcare, education planners, etc. Thus, smart software and deep learning programs become more and more critical for mathematical modeling and algorithms of many educational relations. It is an inevitable necessity to make sense of educational studies about 
education and to create valid inferences about the future in order to make the right decisions and forecasts in the world of the future.

\subsection{Model and Procedures of the Research}

In this study, it is aimed to identify and interpret the factors that cause difficulties, spoil learning and cause disruption in the learning-teaching processes developed to reach the basic objectives, root values, and competencies in general education system.

While determining the research method, the subject of the research, the research process, obtaining the data, and the data analysis process was evaluated together. Accordingly, since the research aims to reveal the existing situation under its conditions, it adopts the descriptive scanning model, which is included in the types of survey type research. Within the frame of this model, it is started with the literature review. The keywords and the variables of the research (Table 2) were obtained during the literature review. During the literature review, the time interval, the inclusion and exclusion criteria, and the frames of the databases for the literature review were determined. Following the findings of the research grouped according to these criteria are evaluated, six themes were determined as "technology and media", "exams", "school, education system and educational practices", "addiction", "health" and "environment". Considering the data studied and the process followed; descriptive content analysis, one of the non-interacting qualitative research designs, was used. (Dinçer 2018, Karataş 2015). Thus, objective reality, literature trends, and research results obtained in line with the research questions were evaluated descriptively and systematically.

Content analysis is a scientific method that is generally compiled by systematically examining written materials, grouping them with certain criteria, and compiling them to spread knowledge and guide future research. (Dinçer 2018). Qualitative data are analyzed via content analysis or descriptive content analysis. (Karataş 2015). The main purpose of the descriptive content analysis is to determine the trends, it is done by systematically coding the quantitative or qualitative data within the framework of certain themes and classifications. (Cohen et al. 2007, Fraenkel, et al. 2007). In this research, the systematic definition and evaluation of the research results obtained with the help of the criteria (Table 2) determined by the researcher were carried out by descriptive content analysis (Çalık \& Sözbilir 2014). Descriptive content analysis is a type of qualitative data analysis that includes summarizing and interpreting the data obtained with various data collection techniques according to predetermined themes (Berg and Lune 2015, Özdemir 2010, Glesne 2014). Qualitative analysis is a technique that enables researchers to understand how social events and phenomena occur. To this end, in qualitative research, the goal is to search and make sense of variables rather than evaluation of these variables. Therefore, descriptive content analysis was used in the current study to analyze and make sense of both qualitative and quantitative research findings. Thus, generality, objectivity, systematicity, reliability, and controllability features were provided in the study. In this study, 238 qualitative and quantitative research conducted between 2014-2018 were investigated within the framework of determined criteria, and descriptive content analysis was used as a method (Çalık, Sözbilir, 2014).

The descriptive content analysis was carried out in six steps:

In the first step; purpose, subject and research questions were determined, and a framework (Table 1) was formed by the researcher for descriptive analysis.

Table 1. Framework Structure Used in Descriptive Content Analysis

\begin{tabular}{|c|c|c|c|c|}
\hline & $\begin{array}{c}\text { Type of } \\
\text { Publication }\end{array}$ & $\begin{array}{l}\text { Description of the } \\
\text { Literature }\end{array}$ & The Results of the Publication & $\begin{array}{c}\text { The Codes } \\
\text { Obtained from the } \\
\text { Publication }\end{array}$ \\
\hline & ( & ( & ,",,,,,,,,,,,,,,,", & ( \\
\hline $\begin{array}{c}\text { Name of } \\
\text { The }\end{array}$ & 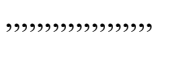 & 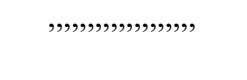 & 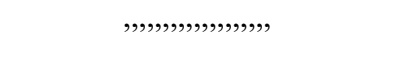 & Implication \\
\hline Category & , & 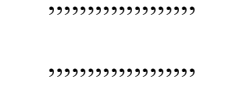 & 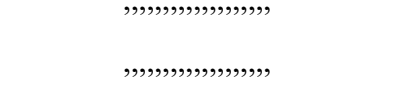 & 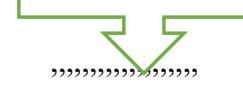 \\
\hline
\end{tabular}

In the second step; literature was reviewed. The keywords used in the literature review, databases, and the time period (Table 2) were determined.

In the third step; title - abstract and results of the chosen (candidate) literature were reviewed firstly. Then, literature, which was compatible with the aims and questions of the research, was included in the research, and all 
these studies were examined.

In the fourth step; content of this selected literature was created in a table form. (Appendix II)

In the fifth step; codes and categories, and findings were defined according to the previously determined thematic framework through descriptive content analysis. Finally, inductive inferences were made by synthesizing the themes obtained from the studies investigated.

In the sixth step; findings were correlated, made sense of, interpreted and reported in the analysis process.

\subsubsection{Reliability and Validity}

The purpose and questions of the research were clearly stated to ensure validity and reliability in this study. The data collection method, inclusion and exclusion criteria (Table 2) were determined for the validity of the findings. Accordingly, 25 sub-item analyzes of the studies under 6 items included in the analysis according to the template in Table 1 were analyzed individually (on 25 tables), and then descriptive content analysis was conducted from these tables. The process of analysis of data and preparation of the findings under common themes were explained. The analysis was done by two academic staff. Correlation between raters was determined as rp $=0.94$. Inter-rater reliability $=$ Consensus $/$ (Agreement + Disagreement) (Miles and Huberman 1994) reliability formula was used in determining the agreement between raters, and a high degree of correlation was found. Descriptive content analysis process lasted about one year.

\subsection{Sampling and Limitations}

The literature used in the current research is limited to research between 2014 and 2018 (5 years). The literature review was carried out by the researcher in various time periods between 2014 and 2018. The analysis was done by two academic staff. Since the research primarily dealt with educational problems in Turkey, academic publications that belong to Turkey, theses and articles whose issues, problem state, data, and analysis were included in the analysis in the process of literature review. In the present research, "inclusion" and "exclusion criteria" are given in Table 2.

\subsection{Keywords, Databases, Calendar, Period of Time, Inclusion and Exclusion Criteria}

The criteria used in obtaining research data are given below.

Table 2. Keywords Table Used in the Research, Databases, Schedule, Timeframe, Inclusion and Exclusion Criteria

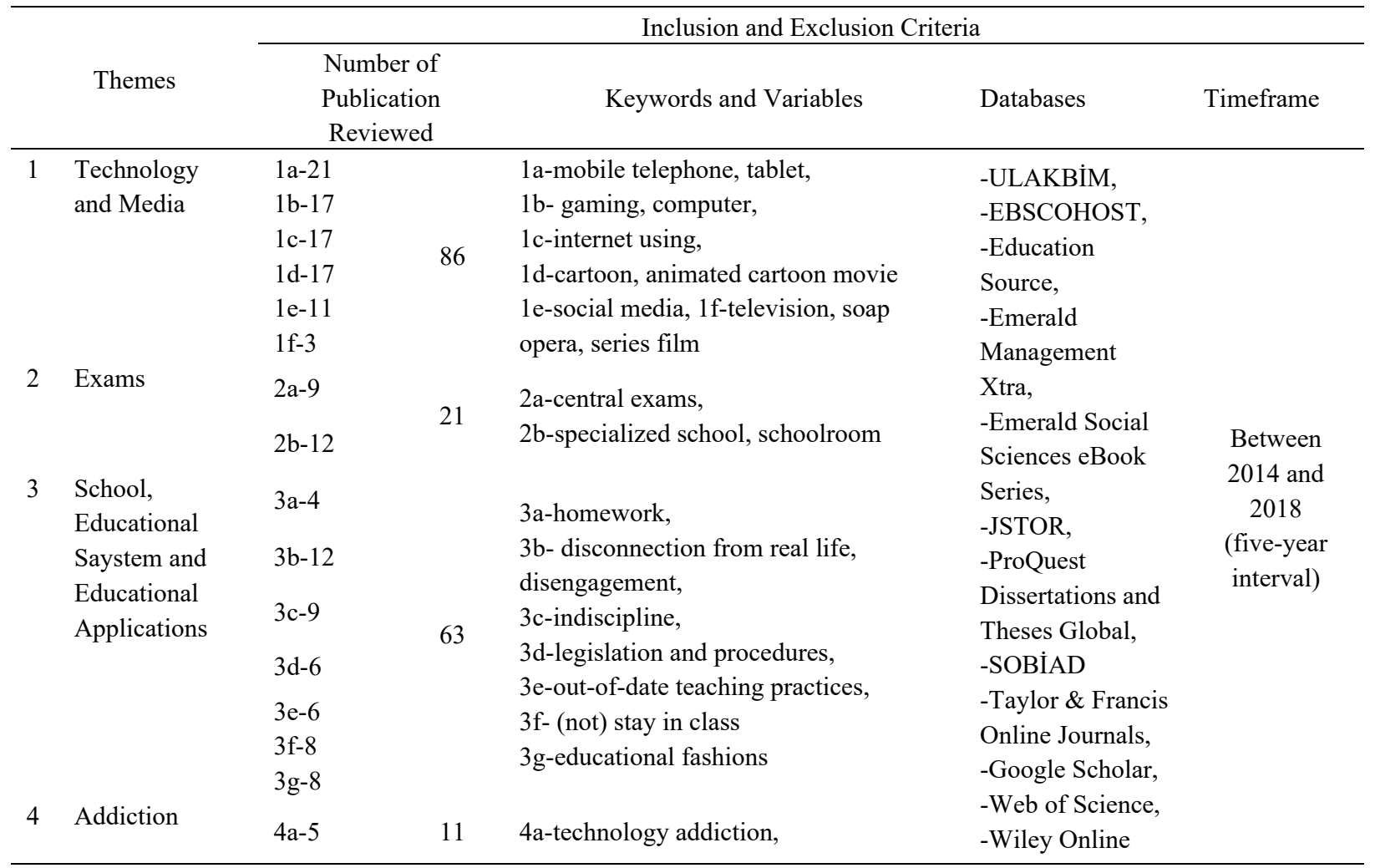




\begin{tabular}{|c|c|c|c|c|c|}
\hline \multirow{5}{*}{5} & \multirow{5}{*}{ Health } & \multicolumn{2}{|l|}{$4 b-6$} & $\begin{array}{l}\text { 4b-substance abuse, } \\
\text { smoking-drinking-drug addiction }\end{array}$ & \multirow{5}{*}{$\begin{array}{l}\text { Library, } \\
\text {-OMU Library, } \\
\text {-YÖK/ HEC } \\
\text { National Thesis } \\
\text { Center }\end{array}$} \\
\hline & & $5 a-12$ & \multirow{4}{*}{40} & 5a-ohesity & \\
\hline & & $5 \mathrm{~b}_{-} 9$ & & bb-excessive consumption culture & \\
\hline & & $50-9$ & & $5 c$-unhealthy eating & \\
\hline & & $5 c-19$ & & & \\
\hline \multirow[t]{7}{*}{6} & Environment & $6 a-4$ & & & \\
\hline & & $6 b-2$ & & 6a-violence, & \\
\hline & & $6 c-3$ & & 6c-peer bullying, & \\
\hline & & $6 \mathrm{~d} 4$ & 17 & 6d-moral collapse, & \\
\hline & & bd-4 & & 6e-noise pollution, idle talk, not & \\
\hline & & $6 e-4$ & & listening to others & \\
\hline & 6 themes & & $\sum=238 *$ & *See Appendix II for referance literature & \\
\hline
\end{tabular}

*See Limitations

\section{Findings}

In the present study, the factors that hinder, negatively affect, disrupt, slow down, reduce and restrict the learning quality, and how these factors affect education learning, education and especially learners were aimed to describe. For this purpose, the meta-synthesis findings related to the research questions are given below.

3.1 Under the Theme of Technology and Media; Findings Related to Mobile Phones, Tablets, Computers, Games, Internet, Cartoons, Social Media, Television, TV Series, and How These Variables Affect Learning, Education and Learners

3.1.1 Under the Theme of Technology and Media; Descriptive Content Analysis on How "Phone and Tablet" Variables Affect Learning, Education and Learners.

Inferences and synthesis were made from the sources and codes regarding the variables in the "phone and tablet" category that affect learning, education and students under the theme of technology and media. In this light, it is safe to claim that excessive, uncontrolled and misuse of tablets and mobile phones may deprive learners of outdoor games, cause behavioral problems, affect their sleep time negatively, and have negative effects on children regardless of gender. Nomophobia is a major problem among university students, and as smartphone usage time increases, addiction (nomophobia) increases (Abuah, Schilder, Sherman, Martin 2018; Aljomaa, Qudah, Albursan, Bakhiet, Abduljabbar, 2016; Altun, Gülay 2018; Andreassen, Billieux, Griffiths, Kuss, Cha, Seo 2018; Demetrovics, Mazzoni \& Pallesen 2016; Erdem, Kalkın, Türen, Deniz 2016; Hawi, Samaha 2016; Hosokawa, Katsura 2018; Johansson, Gustafsson 2016; Gokçearslan, Kus, Mumcu, Haşlaman, Çevik 2016; Gökmen, Duman, Akgün 2018; Korkmaz vd. 2015; Kutlu \& Pamuk 2017, Lian, You, Yuang, Yang 2016; Lopez-Fernandez, Männıkkö, Käärı̈ınen, Griffithsand Kuss 2018; Nathanson, Beyens 2018; Neumann, Neumann 2014; O Connor 2017; Peker 2014; Van Deursen, Bolle, Hegner, Kommers, Piet 2015; Yılmaz Genç \& Fidan 2017; Yeni, 2015; Zhitomirsky-Geffet, Blau 2016).

3.1.2 Under the Theme of Technology and Media; Descriptive Content Analysis on How "Game (Computer)" Variable Affects Learning, Education and Students

Under the theme of technology and media, inferences and syntheses were made from the sources and codes regarding the variables in the "Game (Computer)" category and how it affected learning, education and students. Accordingly, it can be argued that games cause social loneliness, negative family relationships, virtual bullying and offer negative role models to children. They also cause negative psychological effects, sleep disorders, and failure in academic success. Further, it is noted that as the aggression increases in computer games, the feeling of empathy decreases; playing digital games causes early adolescence and limits the duration of communication with parents (Bülbül, Tunç, Aydil 2018; Çankaya, Ergin 2015; Çavuş, Ayhan, Tuncer 2016; Fiona, Kayleigh, Nigel, Neil 2016; Fryling, Cotler, Rivituso, Mathews, Pratico 2015; Hawi, Samaha, Griffiths 2018; Kardefelt-Winther 2017; Laffan, Greaney, Barton, Kaye 2016; Lopez-Fernandez, Männıkkö, Käärı̈ınen, Grıffıths, Kuss 2018; Niko, Heidi, Zsolt, Olatz, Laura, Jouko, Maria 2017; Quan, QI, QI 2015; Saglam, Kayaduman, Delialioglu 2016; Savannah 2018; Say, Bağ 2017; Shi, Boak, Mann, Turner 2018; Torun, Akçay, Çoklar, Karaelmas 2015; Tutkun, Demirtaş, Açıkgöz, Tekşal 2017). 
3.1.3 Under the Technology and Media Theme, Descriptive Content Analysis on How "Use of Internet" Variable Affects Learning, Education and Students

Under the theme of technology and media, inference and synthesis were made from the sources and codes regarding the variables in the "Use of Internet" category that affect learning, education and students. Correspondingly, the individuals between the ages of 1-24 use the internet about 5-6 hours a day, and they usually use it for communication purposes. It is also stated that the media literacy lesson in the school program is inadequate, and media of internet is used as an exploitative material for children and has a shaping effect on structure and order of the society and quality of the relationships (Açıalın 2017; Akdağ 2016; Altun 2014; Altun 2009; Arslan 2016; Aslan 2004; Aydın 2013; Aydın 2016; Barkan, Eroğlu 2014; Durak, Seferoğlu 2016; Ismail, Hasan 2017; Kihtir 2011; Oktik 2013; Özarslan, Şener 2015; Şimşek 1996; Tosun, Geçer, Kaşıkc1 2016; Ulusoy 2017; Tomczyk, Wąsiński 2017).

3.1.4 Under the Theme of Technology and Media, Descriptive Content Analysis on How "Cartoon / Comics" Variable Affects Learning, Education and Students

Under the theme of technology and media, inference and synthesis were made from the sources and codes about the variables in the category of "cartoons/comics" affecting learning, education and students. On the relevant question, it is found that especially preschool children perceive cartoons characters as real, and their behaviors are affected by them; archetypes (template icons) are often used in cartoon channels in the majority of cartoons, in which children take heroes in cartoons as models; and the stimuli is given to the subconscious form cultural codes and archetypes. Also, it is stated that mostly negative old image is used in comics, and some cartoons contain subliminal messages; negative images and many types of violence, especially physical violence are placed in the subconscious of children with the cartoon mask of violence. On the other hand, it has been revealed that the level of consciousness of the parents is low in these issues (Akkuş, Yılmazer, Şahinöz, Sucaklı 2014; Altınkılıç 2014; Beldağ, Kaptan 2017; Curga 2014; Çakmak, Koç 2015; Çipan 2014; Darıc1 2015; Intusomaa, Mo-Suwana, Ruangdaraganonb, Panyayongc, Chongsuvivatwongda 2013; Karakuş 2015; Kırtepe 2014; Kostyrka-Allchorne, Cooper, Simpson 2017; Okuma, Tanimura 2009; Özdemir, Ramazan 2012; Savaş, Doruk (2018).; Temel, Kostak, Çelikkalp 2014; Temizyürek, Acar 2014; Tuncal, Yücel, Bal Tepe, Alıcı Hoşgören, Kırıcı, Baştuğ, Özel Kızıl 2017; Yetim, Sarıçam 2016).

3.1.5 Under the Theme of Technology and Media, Descriptive Content Analysis on How "(Social) Media" Variable Affects Learning, Education and Students

Under the theme of technology and media, inference and synthesis were made from the sources and codes regarding the variables in the "(social) media" category and how this variable affected learning, education and students. Obviously, it is revealed that the most preferred social network is Facebook, and emotional and behavioral problems (loss of time, shyness, self-esteem, change of mood and dissatisfaction), and emotional and behavioral disorders such as anxiety, stress, depression, loneliness, fear of missing out, feeling worthless, hopelessness, helplessness, distress and avoiding social environments may occur in young people (Akgündüz, Akınoğlu 2017; Aydın 2016; Aylk 2017; Cesur, Memiş, Gökkaya 2016; Durak, Seferoğlu 2016; Gö̧̋oğlu, Aydın 2015 Görü Doğan 2015; Gündoğdu 2016; Kartal, Yazgan, Kıncal 2017; Kılıç, Koç, Okumuş, Parlar 2018; Koçyiğit 2017).

3.1.6 Under the Theme of Technology and Media, Descriptive Content Analysis on the Subject of "Television and (TV Series)" and How this Variable Affects Learning, Education and Students

Under the theme of technology and media, inferences and synthesis were made from the sources and codes regarding the variables in the "Tv and (series) movies" category and how this variable affected learning, education and students. Considering the findings, it has been noted that children watch television over the recommended time period, and they have some health problems, especially in their eyes and sleep in case of long-term television watching. Along with all these, socio-economic structure of the family is an important determinant of children's television habits and some hidden advertising implementation in the series (Açıkalın 2017; Çiçek 2017; Kapucu, Seçkin 2014).

3.2 Under the Theme of Exams; Findings of Descriptive Content Analysis on Central Exams, Lecturers on Learning Variables, Education and How They Affect Students Negatively

3.2.1 Under the Theme of Exams, Descriptive Content Analysis on How "Central Exams" Variable Affects Learning, Education and Students

Under the theme of technology and media, inference and synthesis were made from the sources and codes regarding the variables in the "central exams" category and how it affected learning, education and students. In this way, it is found out that examination system in Turkey distracts schools from focusing their purposes and push school 
education into background, and exams become the main purpose of education in all grades. Besides, teachers prepare courses and exams that are central exams oriented, and they prepare questions that may be asked questions in the central exams students, and this situation ignores the development of the learners as a whole, and the education system is exam-oriented and is far from evaluation of knowledge, skills and abilities, and students perceive lessons and subjects that do not have questions in central exams as a waste of time, and they have conflict with the teachers of these lessons, and the students who will take the exam have anxiety and this affects sleep quality negatively, and successful learners may have communication problems between the their friends and the environment, the content and philosophy of the curriculum and the central exams are not compatible, and the constantly changing exam system, types of questions and contents affect the success of the students negatively, and the demand for private schools has increased due to the fact that unrealistic (inflated) grades have been given to the top student of high school and the average of high school grades play an important role in the entrance to the university, and in addition, central exams cause problems that are difficult to repair economically, socially, culturally and psychologically in a large part of the society (Can 2017; Çetin, Ünsal 2018; Gürbüz, Erdem, Temurtaş, Koç 2015; Kumandaş, Kutlu 2014, Kumandaş, Kutlu 2015; Selmin Köse, Kurucu Yılmaz, Göktaş 2018; Özcan 2016; Yılmaz 2017; Yılmaz, Bülbül 2017).

3.2.2 Under the Theme of Exams, Descriptive Content Analysis on the Theme of "Private Courses", How They Affect Learning, Education and Students

Under the theme of technology and media, inference and synthesis were made from the sources and codes regarding the variable in the "private courses" category and how they affect learning, education and students. In accordance with the research question, it is determined that families spend the highest education expenditure for private lessons and private teaching institutions before the entrance to high schools and universities. In spite of the fact that the teachers in the Ministry of National Education (MoNE) have high perceptions of competence, they believe that the private teaching institutions are a requirement for education system, and most of the students think that they should go to private education. At the same time, according to Turkey Statistical Institute (TSI, 2015), while the highest part of the $20 \%$ share of the total revenue $45.9 \%$ in Turkey, the same rate is only $6.2 \%$ for the lowest twenty percent cut. This means that the wealthiest section of society has 7.4 times more income than the poorest section. It is also worth noting that the emergence of private teaching institutions is due to the inadequacy of equal opportunities, and the higher the socio-economic levels of families bring, the higher the rate of sending to the private teaching institutions (Aksoy 2018; Alkan, Acarlı, Altundağ 2017; Arı, Yılmaz 2015; Aslan 2017; Ataç 2017; Ekinci 2011; Karabay 2014; Memduhoğlu, Kayan 2017; Özgen, Köşker, Yalçın 2014; Özgen, Köşker, Yalçın 2015; Şimşek, Şimşek 2015; www.tuik.gov.tr 2019).

3.3 Under the Theme of School, Education System and Education Practices; Descriptive Content Analysis findings on Homework, Disconnection from Real Life, Discipline, Legislation and Procedures, Outdated Teaching Practices, Failure in Classroom, Learning about Educational Fashion Variables, and How They Affect Students Negatively

3.3.1 Under the Theme of School, Education System and Education Practices; Descriptive Content Analysis on How "Homework" Variable Affects Learning, Education and Students

Under the theme of school, education system and education practices, inferences and codes were inferred from the sources and codes regarding the variable in the "assignment" category and how it affected learning, education and students. Accordingly, it is uncovered that the students do not understand the homework clearly, which is the most common problem about homework, and most students do their homework due to necessity, fear and anxiety of the results, and some students think doing homework as a time-wasting activity, and they do not like doing homework such as writing and reading, and when they do not do their homework, they are punished by the teacher or given them more difficult and additional homework, and this situation causes frustration in students (Duru Çögmen 2017; Güneș 2014; Özdemir, Erdemci 2014; Şeref, Arrivaloğlu 2015)

3.3.2 Under the theme of school, Education System and Education Practices; Descriptive Content Analysis on "disconnection from real life" Variable and How It Affects Learning, Education and Students:

Under the theme of school, education system and education applications, the inference and synthesis were made from the sources and codes about how the variable in the "real-life disconnection" category affected learning, education and students. In the long run, although the goal of the education was to prepare the student for life and a higher education, it was understood that the schools were far from preparing students for life, and those who had been taught in schools for years in compulsory and formal education could not be used in real life (Arseven 2015, Ben-Shahar 2015, Du, Zhang 2014, Haug 2017, Gelen 2018, Griswold, 2016, Hidayah 2016, Korkealehto, Siklander 2018, Kyriaki 2017, Lebedev 2017, Maharaj 2017, Matt, Cathie, Nerida, Austin \& David 2014). 
3.3.3 Under the Theme of School, Education System and Educational Practices, Descriptive Content Analysis on How the "discipline" Variable Affects Learning, Education and Students

Inference and synthesis were made from sources and codes regarding the variable in the "discipline" category on how it affected learning affects education and students under the theme of school, education system and education practices. Taken together, it is noted that academic failure, dishevelment in school uniform, fighting, smoking, verbal insults, theft, disrespectful behavior towards the teacher, and disciplinary problems related to cheating, violation of classroom and school rules, attitude, developmental period, responsibility and substance use disorders and undisciplined behaviors in the classroom are among the most common problems of the learners in high schools. In addition, standing around the classroom during the course, getting the items from others without permission, damaging the school belongings, ignoring the teacher, disrespecting the teacher, hostile competition, inappropriate behaviors that occur between girls and boys, modeling the negative characters in the TV series, unpreparedness for the lesson, not doing the homework and bringing the necessary course material also caused discipline problems. What is more, indecent dressing, chewing gum in the lesson and using a phone tablet, being absent, leaving the lesson without permission, coming to class late, trying to leave the teacher in a difficult situation, categorizing the lessons as important and unimportant, reflecting the negative attitude of the family to the school and using harmful substances, making unnecessary noise, verbal abuse to other students, using a mobile phone during the lesson, physical aggression towards other students, speaking without taking a word in the lesson, irresponsibility, disrupting the course flow, playing with a mobile phone in the lesson and chewing gum, swearing, using nicknames for friends, ignoring other people while talking, being disrespectful towards their teachers, not obeying the rules of dressing, being absent or late for class, smoking, behaving like characters in movies and giving damage to school objects, negative examples on TV and internet, students' developmental characteristics, family problems, grouping among students were the behaviors that disrupted discipline in the classroom. The inadequate and unfair behaviors of teachers also caused discipline problems (Can, Ermeydan 2017; Durak, Seferoğlu 2017; Kılıç 2015; Öztürk 2016; Polat, Arslan, Satıcı 2016; Sadık, Aslan 2015; Sadık, Öztürk 2018; Tunç, Yıldız, Doğan 2015; Uysal 2016; Vatansever Bayraktar, Kaya 2017).

3.3.4 Under the Theme of School, Education System and Educational Practices; Descriptive Content Analysis on How the "Legislation and Procedures" Variable Affects Learning, Education and Students

Under the theme of school, education system and educational practices, inferences and syntheses were made from sources and codes regarding the variable in the "legislation and procedures" category on how it affected learning education and students. In this sense, frequent changes in legislation, problems in appointments of the staff, excessive workload, undesired increase in working hours, legislation and bureaucratic issues affected managers negatively. Excessive workload, paperwork, documents to be replied urgently and tension caused after that works were identified as the most important source of stress in managers. Necessary-unnecessary paperwork and official correspondence cause waste of energy, time and effort; and conflicts in legislation and lack of unity in practice increase the degree of complexity of the work, low motivation and job satisfaction (Aksoy 2017; Balıkç1 2016; Büyükoğlu 2015; Çelebi, Övür, Eravc1 2017; Erol 2015; Met 2016).

3.3.5 Under the Theme of School, Education System and Education Practices; Descriptive Content Analysis on "Out-of-Time Teaching" Variable and How it Affects Learning, Education and Students

Under the theme of school, education system and education applications, inference and synthesis were made from the sources and codes about how the variable in the "out of time teaching practices" category and how they affected learning, education and students. Based on the research question, it is revealed that teachers use traditional teaching approaches and methods, and they tend to practice the same lesson every year without making any change. They cannot keep up with new methods and techniques and have difficulty in keeping up with the changes in the programs, and therefore, use the same approach in classroom management. They do not know using educational technology adequately and actively, and their knowledge about multiple and alternative assessment and evaluation techniques are insufficient or inadequate (Aliakbari \& Hemmatiza 2015; Cai 2017; Demircioğlu \& Demircioğlu 2016; Gelen 2018, Kuksina \& Sokolova 2014; Salama 2014; Wirussawa, Tesaputa, Duangpaeng 2016).

3.3.6 Under the Theme of School, Education System and Education Practices: Descriptive Content Analysis on "Failure in the Classroom or Not"

Under the theme of school, education system, and education practices, inference and synthesis were made from the sources and codes about the variable in the "failure in the classroom or not" category and how it affected learning, education and students. All things considered, it is noted that low possibility of failing in the classroom in compulsory education restricts the efforts of the students, and causes drowsiness and irresponsibility. Therefore it 
causes discipline problems and irresponsibility. It is also stated that high probability of passing classroom for each student may lead to greater problems both individually and socially in the future because of the notion that failure in class may cause an economic burden. Further, it is revealed that there is a relationship between traditional evaluation system and failure in class (Arslan, Polat 2016; Bektaş, Akdeniz Kudubeş 2014; Berkant, Efendioğlu, Sürmeli 2014; Cerit, Akgün, Yıldız, Soysal 2014; Gezgin 2016; Küçüker 2017; Polat, Arslan, Seller 2016; Yorgun 2014).

3.3.7 Under the Theme of School, Education System and Education Practices; Descriptive Content Analysis about How the "Education Fashions" Variable Affects Learning, Education and Students

Under the theme of school, education system and educational practices, inference and synthesis were made from sources and codes about the variable in the "educational fashions" category and how it affected learning education and students. Accordingly, mental arithmetic, NLP, structuralism, multiple intelligence practices, STEM, learning styles, robotic, Education 4.0-5.0, cloud computing, xyz- $\beta$ - $\alpha$ generation fashion, project fashion, education of moral values fashion, course materials / supplementary books fashion, private school fashion, Bologna Fashion, flipped learning fashion, TQM (total quality managament) Fashion, distance education, home school, etc. many new research and application issues, especially unknown in private schools are being applied and thought as a solution for everything. This means a waste of generation, time, labor, and money. (Biesta 2015, Hanganu 2015, Lamanauskas 2017, Launer 2015, Nugent 2017, Plessis 2015, Reno 2014, Vansover 2017).

3.4 Under the Theme of Addiction; Descriptive Content Analysis and Findings Regarding Technology Addiction, Smoking-Alcohol-Drug Addiction Variables, and How They Affect Learning, and Students Negatively

3.4.1 Under the Addiction Theme "Technology Addiction", Descriptive Content Analysis Variable and How It Affects Learning, Education and Students

Under the theme of addiction, inference and synthesis were made from the sources and codes regarding the variable in the "technology addiction" category, how it affected learning, education and students. Considering the findings, Turkey ranks fifth in the world with 7.8 hours in a week in terms of the time spent per visitor on Facebook. Internet addiction causes occupancy problems for information systems constantly and increases misuse instead of using it productively, and loss of work/time and energy. It causes psycho-social behavioral disorders and makes real-life complicated. This situation causes harm for people in many areas such as health, social, education, and interpersonal relations. It is stated that internet addiction will increase gradually and have a negative impact on human health. More than half of university students and nearly half of public officers are nomophobic (fear of mobile phone deprivation). University students spend their free time using a smartphone, which is associated with nomophobic behaviours. It has been found that the average smoking duration of students with internet addiction was higher than the group without internet addiction (Alaçam, Çulha, Ateşci, Şengül, Tümkaya 2015; Koç, Albayrak 2017; Savci, Aysan 2017; Ulusoy 2017; Y1lmazsoy, Kahraman 2017).

3.4.2 Under the Addiction Theme, Descriptive Content Analysis on How "Substance Abuse (smoking-alcohol-drug)" Variable Affects Learning, Education and Students

Under the theme of addiction, inference and synthesis were made from the sources and codes regarding the variable in the category of "substance addiction (cigarette, alcohol, drug addiction)", and how they affected learning, education and students. It may not be wrong to state that the most important factors for students' addiction are the circle of friends, easy accessibility, enthusiasm and curiosity, increasing number of adolescents who smoke and take alcohol around, together with the fact that students start smoking with the most curiosity and friend effect, loneliness, wannabe, family problems, school problems and behaviors of learners to prove they have grown up, and the period in which students start using harmful substances most often is high school, and learners can easily access addictive substances, and that parents' attitudes about this issue are not so strict, and media and internet are mostly the sources for obtaining information about substance addiction have been reported. However, it was stated that among the students who had discipline problem and low academic performance, smoked, took alcohol or used substance or received psychological treatment academic success and the ones who were in trouble with the police, absent from the school mostly, the rate for smoking and alcohol were statistically significantly higher (Akkus, Karaca, Konuk Şener, Ankaral 2017; Retired, Çıtıl Önder, Bulut, Yaşayancan, Kazanc1, Sönmezgöz, Eğri 2017; Erdamar, Kurupınar 2014; Erdem, Türen, Get Up 2017; Özay Köse, Gül, Keskin 2017; Ulusoy 2017). 
3.5 Under the Theme of Health; Descriptive Content Analysis Findings on Obesity, Excessive Consumption Culture, Unhealthy Nutrition Variables, Learning and How They Affect Students Negatively

3.5.1 Under the Theme of Health, Descriptive Content Analysis on “Obesity” Variable and How It Affects Learning, Education and Students

Under the theme of health, inferences and synthesis were made from the sources and codes about the variable in the "obesity" category and how it affected learning, education and students. Accordingly, as the body mass index values of the parents increase, the frequency of obesity in children increases, and the frequency of obesity is higher in children who spend more than 4 hours a day in front of TV and computer. Sales of unhealthy products in school canteens is considered to be among the reasons for obesity, and obesity increases as eating healthy food decreases. Three of the individuals in four young adults do not have healthy eating habits, and high-socioeconomy of the families affects eating habits. Obesity is not only a health but also a psychological problem, and junk foods are low in fiber and vitamin, and animal source food, potato-corn chips, fast food, sugary drinks, cause unhealthy nutrition and obesity. More than 1/3 of Turkish people find themselves overweight, and canteens change students' eating habits, and they do not care about breakfast at home in the morning, and when they come from school and snack at school, they do not eat home (Aksoy 2017; Ayyıldız, Demirli 2015; Balcı Çelik, Vural Batık, Özcan, Aksoy 2015; Doğan, Uğurlu, Çetinkaya 2015; Emlek Sert, Bayık Temel 2017; Hilal Yayan, Çelebioğlu 2018; İskender, Tura, Akgül, Turtulla 2014; Özilbeya, Ergör 2015; Savaşhan, Sarı, Aydoğan, Erdal 2015; Tözün, Sözmen, Babaolu 2017; Yıldırım Aksakal, Oğuzöncül 2017; Yüksel, Adıyaman, Keçeli, Doruk, Yavuz Kasdemir 2014).

3.5.2 Under the Theme of Health, Descriptive Content Analysis on "Overconsumption Culture" Variable That Affects Learning, Education and Students

Under the theme of health, it was inferred and synthesized from the sources and codes regarding the variable in the category of "overconsumption culture" affecting learning, education and students. Fairly, it was tried to impose an overconsumption culture to children through media tools, and parents were encouraged to buy something for their children in ads. It was also stated that as the income of the parents increased, conspicuous consumption of individuals increased. The rate of people who never consume red meat constitutes one of the five persons in Turkey. Children are tried to be today's consumers and tomorrow's loyal customers through marketing strategies, and consumption is an identity building and has an expressive aspect. Also, consumption tendencies of young individuals are largely influenced by the symbolic (brand etc.) meanings offered by the objects, and family is the most crucial factor in determining the consumption behavior of the individual or socialize as a consumer (Ahraz 2017; Başta 2016; Boğa, Başc1 2016; Dal ve Dal 2015; Ezmeci, Çoban Söylemez, Akgül, Akman 2017; Gönül 2018; Kartal 2017; Mammadova 2015; Taşdelen 2016).

3.5.3 Under the Theme of “Unhealthy Nutrition" Variable; Descriptive Content Analysis on Learning, Education and Its Effects on Students

Under the theme of health, we inferred and synthesized the sources and codes about the variable in the category of "unhealthy nutrition" that affected learning, education and students. Accordingly; education by families is essential for developing healthy eating habits; university students have nutritional disorders such as skipping breakfast, eating large portions of food, low-quality food consumption; popular culture, TV ads and desire for spending money individually negatively affect natural eating habits; students mostly give importance to the taste of the food, and then its healthiness; they pay attention to the preparation time and price lastly; $92,5 \%$ of students in Turkey eat fast, and 79.4\% of them skipping meals (mostly breakfast; nutritional imbalance affect mental performance, desire to work, academic success, attention and perception negatively and causes health problems; some of the students never consume eggs, vegetables, milk and dairy products and meat and meat products but they mostly eat candy, honey, jam, chocolate sweet, and it has been found that there is a relationship between unhealthy consumption of foods and beverages and obesity (Aktaş, Özdoğan 2016; Altıncı, Keskin, Türksoy, Güvendi, Doğan 2016; Arıkan, Yavuz, Yiğit, Ece 2017; Bebiş, Akpunar, Özdemir, Kılıç 2015; Dil, Gönen Şentürk, Aykanat Girgin 2015; Erdoğan 2016; İkikat Tümer 2015; İkikat Tümer 2018; Kahraman 2018; Karakaş, Törnük 2016; Meltem Kürtüncü, Uzun, Ayoğlu 2015; Ocak, Kılıçaslan, Yıldırmak, Urgancı 2017; Onurlubaş, Doğan, Demirkıran 2015; Öz 2015; Soylu 2017; Toktaş, Erman, Yetik 2018; Uzdil 2017; Yıldırım, Uskun, Kurnaz 2017; Zembat, Kılıç, Ünlüer, Çobanoğlu, Usbaş, Bardak 2015). 
3.6 Under the Theme of the Environment; Findings of Descriptive Content Analysis Regarding Violence, Swearing and Using Slang, Bullying, Moral Collapse, Noise Pollution, Ignoring Others, Chitchatting Variables, and How They Negatively Affect Education and Students

3.6.1 Under the Theme of Environment, Descriptive Content Analysis on How the Variable of "Violence" Affects Learning, Education and Students Negatively

Under the theme of environment, inference and synthesis were made from the sources and codes regarding the variable in the category of "violence" that affects learning, education and students. In this regard, it has been found that films and programs that contain violence and visual media increase the tendency of violence in young people; negative emotion in students causes cyberbullying; there are security problems stem from the relationships among students or accidents in schools, and there is a shortage of personnel related to these security problems (Emin, Melike 2017; Nevin 2006; Ömer 2017; Özlem, Bertan 2016).

3.6.2 Under the Theme of Environment, "Descriptive Content Analysis on How "Swearing and Using Slang" Variable Negatively Affects Learning, Education and Students

Under the theme of environment, inference and synthesis were made from sources and codes about the variable in the category of "swearing and slang" that affect learning, education and students. Accordingly, it has been reported that social media is a field where swearing and symbolic violence is frequently used, and individuals are manipulated and humiliated through symbolic violence; they are passivated through movements such as offending pride and preventing freedom of expression (Levent 2017; Nagehan 2015).

3.6.3 Under the Theme of Environment, Descriptive Content Analysis on How the Peer "Bullying" Variable Affects Learning, Education and Students Negatively

Under the theme of the environment, inference and synthesis were made from the sources and codes regarding the variable in the category of "peer bullying" affecting learning, education and students. Considering the relevant aspects, it has been found that virtual bullies send electronic messages such as messages, photos, shameful words or slander, which may harm other people through computers and mobile phones; students who use digital media (such as Facebook, Twitter, Instagram) are highly likely to be virtual bullies; as the time of using smartphone increases, the probability of being a virtual bully also increases, and those who use virtual Facebook and Twitter are more likely to be a virtual bully than those who do not use it (Can, Ermeydan 2017; Ünver, Koç 2017).

3.6.4 Under the Theme of Environment; Descriptive Content Analysis on How "Moral Collapse" Variable Negatively Affects Learning, Education and Students

Under the theme of environment, inference and synthesis were made from the sources and codes regarding the variable of "moral collapse" in the category and its effects on education and students. Accordingly, TV broadcasts, newsletters, films, and media have made violence and immorality a part of daily life and make violence and immortality perceived as an ordinary event. In addition, the behaviors that cause discipline problems such as standing around in the class, getting things that do not belong to themselves, damaging school belongings, ignoring the teacher, disrespecting the teacher, behaving like negative characters in the series at school, not preparing for the lesson, not performing the allocated task, not bringing the necessary material, disturbing students and other physically and psychologically and using slang, dressing improperly, chewing gum in the lesson, using a phone or tablet in the lesson, being absent frequently, leaving the lesson without permission, coming to class late, trying to leave the teacher in a difficult situation, attributing the lessons as important and unimportant, reflecting negative behaviors in the family to school and using harmful substances (smoking, drugs) have also been referred to be a result of moral collapse (Ersin, Birgül 2017; Güçlü 2015; Kasap, Mirçık, Dolunay 2018; Kocadaş 2005).

3.6.5 Under the Theme of Environment, Descriptive Content Analysis on How the Variable "Voice Pollution / Chitchatting and Ignoring Others" Affect Learning, Education and Students Negatively

Under the theme of the environment, inference and synthesis were made from the sources and codes about how "noise pollution / chitchatting and ignoring others" affect learning, education and students. In this respect; teachers and administrators state that the biggest activity that creates disciplinary problems is extracurricular noises. It was found that the value of "respect for differences" and the ability to empathize within the scope of education of moral values was effective. At the same time; standing around in the lesson, getting the others' objects, not obeying the rules teacher, behaving the teacher disrespectfully, behaving like negative characters in the series at school, not preparing for the lesson, not performing the task given, not bringing the necessary material, disturbing other students physically and psychologically and using slang language are among the behaviors cause noise (Can, Ermeydan 2017; Dağtaş 2011; Tellan 2011; Yiğit 2017). 


\section{Results and Suggestions}

\subsection{Results}

\subsubsection{Technology / Media Related Results}

/Frequent, uncensored and misuse of tablets and mobile phones can negatively affect children and their sleeping habits; deprive them of outdoor games; cause behavioral problems, and increases nomophobia. In the same way, some games, played electronically in particular, cause loneliness, negative family relationships, virtual bullying, sleep disorders, poor academic success, aggression, communication disorders, early adolescence to say nothing of offering them negative role models. It has been stated that the duration of internet use by children and young people is increasing day by day; some internet media use children for abuse material; media literacy competencies of children and lesson hours of media literacy are insufficient, and the internet has a shaping effect on the structure, order and quality of social relations. It has been found that children model the heroes in cartoons in their lives; archetypes (template icons) that affect children in cartoon channels are frequently used, and stimuli given to the subconscious create cultural codes and archetypes; some cartoons contain subliminal messages; children especially the ones in preschool period perceive cartoons as real and their behavior is affected by cartoons, and parents' level of awareness about this issue is low. It has been revealed that excessive use of social media causes emotional and behavioral problems such as loss of time, shyness, decreased self-esteem, change of emotional state and dissatisfaction in young people; when they cannot access social media anxiety, stress, depression, loneliness, fear of missing out, feeling worthless, hopelessness, desperation, distress and avoiding social environments. It has been figured out that watching for a long time creates some health problems in children (especially eyes and sleeping); hidden advertising is used in the series and the socio-economic structure of the family is determinant on children's television habits.

\subsubsection{Results about Exams and Private Teaching Institutions}

It has been found out that the system of examination distracted schools from their purposes in Turkey, education system was exam-oriented along with being far from assessing skills and abilities and information; exam administration became the main purpose of teachers at all teaching levels, and they organized the lessons and exams for central examination, the lessons were restricted to the topics from which questions could be asked in the central exams, so development of the student as a whole was ignored, the content and philosophy of the curriculum and the central exams were incompatible, constantly changing exam system affected the success of the students; the inflated grades were given in private schools, and the central exams had negative effects economic, social, cultural on the psychological sense on the society. Parents spend the highest education expenses for private lessons and private courses/ teaching institutions; despite the high perception of competence of teachers in the Ministry of National Education (MoNE), they believe that the private teaching institutions are necessary, and most of the students think that they should go to the private education institutions for entrance to university. The emergence of private teaching institutions is due to the inadequacy of equal opportunities.

\subsubsection{Results from the School, Education System and Educational Practices}

The most common problems about homework are that the homework is not understood by the students clearly; most of the students do homework due to necessity, fear and anxiety caused by the results; when the homework is not done, the teacher either punishes students or gives them additional homework and this situation tiredness for the students. It has been found that traditional schools are generally not enough to prepare students for real life, and the information learned in the school is mostly forgotten, and it is not used in real life frequently. It has been determined that there are many different discipline problems in schools. Some of these are related to personal behavioral disorders, while others stem from social disharmony and not obeying rules. On the other hand, it has been stated that teachers should improve themselves on behavioral management strategies. Frequent changes in legislation, official correspondence, and unnecessary paperwork cause the loss of energy, time, and efficiency. It has been revealed that teachers use traditional teaching approaches and methods, and they can not keep up with the latest educational issues professionally; they always use the same approach in classroom management; they do not use the educational technology and multiple and alternative assessments and evaluation techniques adequately and actively. However, it is too easy to pass a grade level in compulsory education, and this causes drowsiness and irresponsibility for students. So, there exists a relationship between traditional assessment and evaluation systems and failure in class. To this end, new applications and approaches regarding education (especially in private schools) are shown as a solution for everything and this causes unprecedented hopes, waste of time, effort and money. 


\subsubsection{Results Related to Addiction}

Social media and internet addiction increase the misuse of technology instead of real needs, causes loss of work/time and energy, and psycho-social behavioral disorders; makes real life more complicated; harm to individuals in many areas such as health, social, education, interpersonal relationships. It has been determined that the most serious factors for substance addiction are friend circle, easy access to the substance, enthusiasm, and curiosity; smoking and taking alcohol among adolescents increase gradually; they can access addictive substances easily; parents' awareness about this issue is insufficient; media and internet information are two of the most common sources that students can learn about addiction and academic success of dependent students is low.

\subsubsection{Health Related Results}

It has been pointed out that frequency of obesity, lack of physical activity and unhealthy eating habits increase in children who spend a long time in front of TV and computer. It has been also stated that obesity is not only a health problem but also a psychological matter, and canteens affect students 'eating habits. It has been determined that through media, excessive consumption culture is tried to be imposed to children; as the income level of individuals increases, conspicuous consumption also increases; children are targeted in marketing strategies as today's consumers and loyal customers of future; family is the most important institution that determines the consumption behaviors or enables the socialization of the individual as a consumer. It has been uncovered that families are important in the acquisition of healthy eating habits; popular culture, advertisements, and the desire to spend money individual negatively affect children's natural eating habits; students mostly care about the tasty foods and then they pay attention to the healthiness, preparation time and price, respectively; students mostly skip meals( mostly breakfasts), this affects mental performance, desire to work, academic success, attention, and perception negatively and cause health problems.

\subsubsection{Conclusions about the Environment}

It has been established that visual media and films, and programs that contain violence increase violent behaviors in young people and cause cyberbullying and security problems, together with the statement that students frequently use swearing and symbolic violence, especially in social media, so individuals are manipulated and passivized. It has been determined that students perform virtual bullying to their peers with computers and mobile phones. All kinds of negative media broadcasts make violent incidents and immorality a part of daily life and make it perceived as an ordinary event by students. It has been found that moral collapse was the basis of the harmful behaviors of the students about themselves and their environment. Educators stated that standing around in the class, taking things that did not belong to themselves, damage to school belongings, ignoring the teacher, behaving to teacher disrespectfully, imitating negative characters in the series at school, not preparing for the lesson, not doing the allocated tasks, not bringing the necessary material, disturbing other students physically and psychologically and using slang were among the activities that created disciplinary problems and these extracurricular noises were effective.

\subsection{Suggestions}

As in the defense ministries of the countries, an education defense system that can detect every factor that causes difficulties in the learning-teaching process, and deterioration and illness in learning and affect society negatively (especially children and young people), and required to establish necessary measures. This system should deal with all aspects of the education and training process and assume an inter-institutional mission because technology, media, exams, school culture, educational practices, addiction, health, and learning environments that affect education should be monitored multidimensionally and continuously. When disease-causing harmful viruses enter a person's body, the immune (defense) system immediately detects that danger and develops a defense mechanism. As in this analogy, all kinds of damaging threats that negatively affect the education and teaching processes should be determined continuously, and the functioning of the education system should be controlled constantly. For this purpose, it is necessary to develop accredited and independent evaluation systems for the continuous monitoring and control mechanism.

\section{References}

Berg, B. L., \& Lune, H (2015). Qualitative research methods in the social sciences (8th ed.). (H Aydın Çev.): Konya, Education Pub. \& Pearson.

Cohen, L., Manion, L., \& Morrison, K. (2007). Research methods in education (5th ed.). London and New York: Routledge Falmer. 
Çalık, M., \& Sözbilir, M. (2014). Parameters of content analysis. Education ve Science, 39(174), 33-38, Https://doi.org/10.15390/EB.2014.3412

Dinçer, S. (2018). Content Analysis in Scientific Research: Meta-Analysis, Meta-Synthesis, and Descriptive Content Analysis. Bartin University Journal of Faculty of Education, 7(1), 176-190. Https://doi.org/10.14686/buefad.363159

Fraenkel, J. R., Wallen, N. E., \& Hyun, H. H. (2012). How to design and evaluate research in education (7th ed.). New York: McGraw-Hill.

Glesne, C. (2014). Introduction to Qualitative Research (4th ed.). (Trans. Edt. A. Ersoy, P. Yalçınoğlu). Ankara, Anı Publication.

Gelen, İ. (2017a). Faculty Members' Expectations and Forecasts Regarding 21st Century Education. International Teacher Education and Accreditation Congress (ITEAC), Proceeding Abstract book, 101-102, Yildiz Technical University \& Marmara University \& Association for Evaluation and Accreditation of Programmes at Faculties of Education (EPDAD), Istanbul, Turkey.

Gelen, İ. (2017b). P21- 21st Century Skill Frameworks in Curriculum and Instruction (USA Practices). The Journal of Interdisciplinary Educational Research, 1(2), 15-29.

Gelen, İ. (2018). Academicians' Predictions of 21st Century Education and Education in the 21st Century. European Journal of Education Studies, 4(5), 165-204. Https://doi.org/10.5281/zenodo.1233478

Karataş, Z. (2015). Qualitative research methods in the social sciences. Spiritual Social Work, 1(1), 62-80.

MEB (2017a). Social Studies Curriculum. Turkey Ministry of National Education, Education Board, p4. Retrieved from http://mufredat.meb.gov.tr/Programlar.aspx

MEB (2017b). Turkish Language Curriculum. Turkey Ministry of National Education, Education Board, 6. Retrieved from http://mufredat.meb.gov.tr/Programlar.aspx

MEB (2017c). Science Curriculum. Turkey Ministry of National Education, Education Board, p5. Retrieved from http://mufredat.meb.gov.tr/Programlar.aspx

Miles, M. B., \& Huberman, A. M. (1994). Qualitative data analysis: an expanded sourcebook. (2nd ed.). Calif. : SAGE Publications.

Özdemir, M. (2010). Qualitative Data Analysis: A Study On Methodology Problem in Social Sciences. Eskişehir Osmangazi University Journal of Social Science, 11(1), 323-343.

Polat, S., \& Ay, O. (2016). Meta-synthesis: A conceptual analysis. Journal of Qualitative Research in Education, $4(1), 52-64$.

Saban, A., \& Ersoy, A. (2016). Qualitative Research Patterns in Education. Ankara, Anı Pub.TDK, 2008. Turkish Language Society, General Türkish Dictionary, TDK Publication, 2349.

\section{Appendix}

\section{Referanced Literature according to Themas}

1-Under the Theme of Technology and Media; Reviewed Literature' Identification related to Mobile Phones, Tablet, Computer, Game, Internet, Cartoons, Social Media, Television, Tv Series, And How These Variables Affect Learning, Education and Learners.

Abuah, C., Schilder, D., Sherman, M., \& Martin, F. (2018). The tablet game: an embedded assessment for measuring students' programming skill in app inventor. Journal of Computing Sciences in Colleges, 33(6), 9-21.

Açıkalın, E. (2017). Protection of Minors Against Mass Media in Turkey in The Context Of Harmonizatıon With The European Union Acquis. Gazi University Faculty of Communication, 3, 2587-1285.

Akdağ, C. (2016). Urban Space and Child in New Media News. OPUS International Journal of Society Researches, 25, 155-180. https://doi.org/10.26466/opus.666726

Akgündüz, D., \& Akınoğlu, O. (2017). The Impact of Blended Learning and Social Media-Supported Learning on the Academic Success and Motivation of the Students in Science Education. Education and Science, 42(191), 69-90. 
Akkuş, S., Yılmazer, Y., Şahinöz, A., \& Sucakl1, İ. (2015). Investigation of Television Watching Habits of Children Between 3-60 Months. Hacettepe University Faculty of Health Sciences Journal. Retrieved from https://dergipark.org.tr/tr/pub/husbfd/issue/7893/103899

Aljomaa, S. S., Al.Qudah, M. F., Albursan, I. S., Bakhiet, S. F., \& Abduljabbar, A. S. (2016). Smartphone addiction among university students in the light of some variables. Computers in Human Behavior, 61, 155-164. https://doi.org/10.1016/j.chb.2016.03.041

Altınkılıç, Z. (2014). Determination Of Mothers' Attitudes And Behaviors About The Effects Of TvWatching Upon The Health Of Children Aged 1-6 Years. Unpublished Mater Thesis. Retrieved from http://earsiv.atauni.edu.tr/xmlui/bitstream/handle/123456789/1242/Z\%C3\%BChal_ALTINKILI\%C3\%87_tez.p $\mathrm{df}$ ? sequence $=1$ \&isAllowed $=\mathrm{y}$

Altun, A. (2009). A Critical Approach to the Selective Media Literacy Course Program from the Viewpoint of Education Science. Ahi Evran University Faculty of Education Journal, 10(3), 97-109.

Altun, T., Gülay, A., \& Mazlum, P. B. S. (2018). Investigating Perceptions Of Teachers' Who Use Interactive Boards For The First Time. Abant İzzet Baysal Univ. Journal of Faculty of Education, 18(2), 634-654.

Altun, Y. (2011). The European Community's The Vision Of Media Literacy Education Within The Frame Of The Recommendations. Yüzüncü Yil University Journal of Education, 8(1), 58-86.

Andreassen, C. S., Billieux, J., Griffiths, M. D., Kuss, D. J., Demetrovics, Z., Mazzoni, E., \& Pallesen, S. (2016). The relationship between addictive use of social media and video games and symptoms of psychiatric disorders: A large-scale cross-sectional study. Psychology of Addictive Behaviors, 30(2), 252-262. http://dx.doi.org/10.1037/adb0000160

Arslan, M. (2016). On the Relationship between Mass Media, Media and Religion. Individual and Society Journal of Social Sciences, 6(1), 5-26.

Aslan, A. (2004). Media's Effects on Individuals. Society and Culture, Journal of Human Sciences, 1(1), 1-12.

Aydın, İ. (2013). Children, Internet and Ethics. Journal of Youth Research, 1(2), 100-119.

Aydın, İ. E. (2016). A Study On Usage Of Social Media Among Univerty Students: Anadolu University Case. Selçuk University Journal of Social Sciences Institute, 35, 373-386.

Barkan, M., \& Eroğlu, E. (2014). Contemporary Environments in Educational Communication: “.. Is communication a source of problem or a solution option?.." The Turkish Online Journal of Educational Technology (TOJET), $3(3), 115-124$.

Beldağ, A., \& Kaptan, S. Y. (2017). An Examination of the Values Contained in Cars Movie. Ahi Evran University Kırşehir Journal of Education Faculty (KEFAD), 18(2), 487-499.

Bülbül, H., Tunç, T., \& Aydil, F. (2018). Game Addiction in Unıversity Students and Its Relationship Wıth Personality Traits and Academic Performance. Academic Review of Economics and Administrative Sciences, 11(3), 97-111.

Cesur, Z., Memiş, S., \& Gökkaya, O. (2016). Evaluating The Advertisements Shown Through Social Media in Terms of The concept of Morality A Review On University Students. TURAN-SAM, 32, 274-290.

Cha, S. S., \& Seo, B. K. (2018). Smartphone use and smartphone addiction in middle school students in Korea: Prevalence, social networking service, and game use. Health Psychology Open. https://doi.org/10.1177/2055102918755046

Çakmak, A., \& Koç, K. (2015). Investigating the Quality of Time Kindergarten Children Spend with Television, Computer, Books, and Toys. Gaziantep University Journal of Social Sciences, 14(2), 513-53.

Çankaya, G., \& Ergin H. (2015). Investigation of Empathy and Aggression Levels According to the Games Children Play. Hacettepe University Faculty of Health Sciences Journal, 1(2), 283-297.

Çavuş, S., Ayhan, B., \& Tuncer, M. (2016). Computer Games and Addiction: A Field Study on University Students. Journal of Communication Theory and Research, 43, 265-289.

Curga, S. (2014). Hidden Advertising Applications in Television Series, İstanbul Kültür Üniversitesi. Sosyal Bilimler Enstitüsü / İletişim Sanatları Anabilim Dalı / İletişim Tasarımı Bilim Dalı Unpublished Master Thesis.Retrieved from https://tez.yok.gov.tr/UlusalTezMerkezi/ 
Çiçek, E. (2017). Social Media In The Context Of Ethics And Visual Readings. The Journal of International Social Research, 10(51), 361-366. http://dx.doi.org/10.17719/jisr.2017.1772

Çipan, A. (2014). Between Consent and Rejection: A Study on Turkish TV Series in Egypt. Unpublished Master Thesis. Retrieved from https://tez.yok.gov.tr/UlusalTezMerkezi/

Darıcı, S. (2015). A Study To Find Out The Effects Of Subliminal Messages Using in Digital Games on Perception of Reality: The Concept of Threshold Of Reality, International Periodical for the Languages. Literature and History of Turkish or Turkic,10(14), 181-202. http://dx.doi.org/10.7827/TurkishStudies.8778

Durak, H., \& Seferoğlu, S. S. (2016). Investıgation of social media literacy and social media usage patterns in Turkey. The Journal of International Social Research, 9(46), 525-535.

Erdem, H., Kalkın, G., Türen, U., \& Deniz, M. (2016). The Effects of No Mobile Phone Phobia (Nomofobi) on Academic Performance among Undergraduate Students. Suleyman Demirel University The Journal of Faculty of Economics and Administrative Sciences, 21(3), 923-936.

Fiona, M. B., Kayleigh, L. C., Nigel, C. S., \& Neil, H. S. (2016). Video gaming in adolescence: factors associated with leisure time use. Journal of Youth Studies, 19(1), 36-54. Https://doi.org/10.1080/13676261.2015.1048200

Fryling, M., Cotler, J., Rivituso, J., Mathews, L., \& Pratico, S. (2015). Cyberbullying or Normal Game Play? Impact of age, gender, and experience on cyberbullying in multi-player online gaming environments: Perceptions from one gaming forum. (JISAR) Journal of Information Systems Applied Research, 8(1), 4-18.

Göçoğlu, V., \& Aydin, M. D. (2015). An Analysİs Of The Relationshıp Between Public Polıcy And Social Media Within The Context Of Social Movements. Journal of International Social Research, 8(37), 880-880. https://doi.org/10.17719/jisr.20153710655

Gökçearslan, Ş., Kus, ,F., Mumcu, K., Haşlaman, T., \& Çevik, Y. D. (2016). Modelling smartphone addiction: The role of smartphone usage, selfregulation, general self-efficacy and cyberloafing in university. Students, Computers in Human Behavior, 63, 639-649.

Gökmen, Ö. F., Duman, İ., \& Akgün, Ö. E. (2018). Teachers' Views About The Use Of Tablet Computers Distributed In Schools As Part Of The Fatih Project. Malaysian Online Journal of Educational Technology (MOJET). https://files.eric.ed.gov/fulltext/EJ1174811.pdf

Görü Doğan, T. (2015). The use of social media in learning processes: learner views on the flipped learning approach. AUAd, 1(2), 24-48.

Gündoğdu, Z. Vd. (2016). Media USe By Preschool-Aged Children. Kocaeli University Journal of Health Sciences, 2(2), 6-10. https://doi.org/10.30934/kusbed.358563

Hawi, N. S., \& Samaha, M. (2016). To excel or not to excel: Strong evidence on the adverse effect of smartphone addiction on academic performance. Computers \& Education, 98, 81-89. https://doi.org/10.1016/j.compedu.2016.03.007

Hawi, N. S., Samaha, M., \& Grıffiths, M. D. (2018). Internet gaming disorder in Lebanon: Relationships with age, sleep habits, and academic achievement. Journal of Behavioral Addictions, 7(1), 70-78. https://doi.org/10.1556/2006.7.2018.16

Hosokawa, R., \& Katsura, T. (2018). Association between mobile technology use and child adjustment in early elementary school age [published correction appears in PLoS One, 2018 Dec 14, 13(12), e0208844]. PLoS One, 13(7), e0199959. https://doi.org/10.1371/journal.pone.0199959

Intusomaa, U., Mo-Suwana, L., Ruangdaraganonb, N., Panyayongc, B., \& Chongsuvivatwongda, V. (2013). Development Effect of television viewing on social-emotional competenceof young Thai children. Infant Behavior \& Development, 36(2013), 679-685.

Ismail, N. F., \& Hasan, M. H. (2017). Literature Review on Technology Usage and Emotional Connection among Children. 2017 International Conference on Research and Innovation in Information Systems (ICRIIS), IEEE Publishers. Https://doi.org/10.1109/ICRIIS.2017.8002538

Johansson, F., \& Gustafsson, L. (2016). Tablets effect on children's mathematical knowledge Degree of Bachelor Dissertation, Faculty of Librarianship, Information. Education and IT. Retrieved from http://urn.kb.se/resolve?urn=urn:nbn:se:hb:diva-12569

Kapucu, S. M. (2014). Opinions of Science Teachers about the Usage of Visual Media during Science and 
Technology Course. Pegem Journal of Education \& Instruction, 4(2), 75-90. Doi: https://doi.org/10.14527/pegegog.2014.010

Kardefelt-Winther, D. (2017). How Does The Time Children Spend Using Digital Technology Impact Their Mental Well-Being, Social Relationships and Physical Activity? An Evidence-Focused Literature Review, Innocenti Discussion Paper. UNICEF Publication. Retrieved from https://www.unicef-irc.org/publications/925-how-does-the-time-children-spend-using-digital-technology-impact -their-mental-well.html

Karakuş, N. (2015). Evaluating the Cartoons That Appeal to Preschool Age in Terms of Their Contribution into the Values Education (The Niloya Case). Journal of Value Education, 12(30), 251-277.

Kartal, O. Y., Yazgan, A. D., \& Kincal, R. Y. (2017). New Determinants of Social Capital in Digital Age: Digital Divide and Social Media Literacy. Ahi Evran University Kırşehir Journal of Education Faculty (KEFAD), 18(2), 353-373. $\mathrm{r}$

Kılıç, M. E., \& Koçyiğit, A. (2017). The Examinatıon Of The Effect Of Social Capital On Innovatıon For Turkey: Spatial Analysis. Journal of Erciyes University Faculty of Economics and Administrative Sciences, 50(2017), 95-120.

Kirtepe, S. (2014). The Effects Of Television Serials on the Community A Socio-Cultural Analysis (Example Of Erzurum). Unpublished $\quad \mathrm{PhD}$ Thesis. Retrieved from https://atauni.edu.tr/yuklemeler/a8d49dad35c0c121deb57a20bdf2f60f.pdf

Kihtir, A. (2011). When Media Education Becomes a State Policy. Istanbul University Faculty of Communication Journal, 40, 25-36.

Koç, A., \& Ayık, Y. Z. (2017). Social Media Assisted Learning: Effects of Using Social Network on Academic Success of Students in 6th and 7th Grade Science Sciences and English Courses. European Journal of Science and Technology, 6(10), 7-19.

Korkmaz, M., Saçan, S., Yücel, A. S., Gürkan, A., \& Kırık, A. M. (2015). Analysis of the Role of Media in Prevention Of Child Abuse and Sexual Abuse. International Journal Of Psychiatry and Psychological Researches, 3(2), 1-32.

Kostyrka-Allchorne, K., Cooper, N. R., \& Simpson, A. (2017). The relationship between television exposure and children's cognition and behaviour: A systematic review. Developmental Review, 44(2017), 19-58.

Kutlu, M., \& Pamuk, M. (2017). Investigation of university students' problematic usage of mobile phone in the context of personality. Journal of Human Sciences, 14(2), 1263-1272. https://doi.org/10.14687/jhs.v14i2.4073

Laffan, D. A., Greaney, J., Barton, H., \& Kaye, L. K. (2016). The relationships between the structural video game characteristics, video game engagement and happiness among individuals who play video games. Computers in Human Behavior, 65(2016), 544-549.

Lian, L., You, X., Huang, J., \& Yang, R. (2016). Who overuses Smartphones? Roles of virtues and parenting style in Smartphone addiction among Chinese college students. Computers in Human Behavior, 65, 92-99. https://doi.org/10.1016/j.chb.2016.08.027

Lopez-Fernandez, O., Männıkkö, N., Käärı̈ınen, M., Griffiths, M. D., \& Kuss, D. J. (2018). Mobile gaming and problematic smartphone use: A comparative study between Belgium and Finland. Journal of Behavioral Addictions, 7(1), 88-99. https://doi.org/10.1556/2006.6.2017.080

Männikkö, N., Ruotsalainen, H., ......Demetrovics, Z., et al. (2018). Problematic Gaming Behavior Among Finnish Junior High School Students: Relation to Socio-Demographics and Gaming Behavior Characteristics. Behav Med, 44(4), 324-334. https://doi.org/10.1080/08964289.2017.1378608

Nathanson, A. I., \& Beyens, I. (2018). The role of sleep in the relation between young children's mobile media use and effortful control.British Journal of Developmental Psychology, 36(1), 1-21. https://doi.org/10.1111/bjdp.12196

Neumann, M. M., \& Neumann, D. L. (2014). Touch Screen Tablets and Emergent Literacy. Early Childhood Education Journal, 42, 231-239. https://doi.org/10.1007/s10643-013-0608-3

O Connor, M. (2017). How does tablet usage by K12 schools impact parent-child homework involvement in Ireland? the University of Dublin Unpublished PhD Dessertation, UK. Retrieved from 
https://www.scss.tcd.ie/publications/theses/diss/2017/TCD-SCSS-DISSERTATION-2017-049.pdf

Oktik, N. (2013). Social Control, Children and the Internet. I. Turkey Children and Media Congress, 297. Retrieved from http://cocukvakfi.org.tr/wp-content/dosya/8k.pdf\#page=298

Okuma, K., \& Tanimura, M. (2009). A preliminary study on the relationship between characteristics of TV content and delayed speech development in young children. Infant Behavior \& Development, 32(2009), 312-321.

Okumuş, V., \& Parlar, J. (2018). Children's Social Media Usage Purposes and Parental AttitudesIstanbul Commerce University. Journal of Social Sciences, 17(33), 357-368.

Özarslan, Z., \& ve Şener, G. (2015). New Media Studies II. National Congress Review. ILEF Journal, 2(1), 151-163.

Özdemir, A., \& Ramazan, O. (2013). Views Of Mothers About Cartoons' Impact on Children' Behaviour. Marmara University Atatürk Education Faculty Journal of Educational Sciences, 35(35), 157-173.

Peker, A. (2014). Investigating The Predictive Role Of Negative Affect On Cyber Bullying and Victimization, Kastamonu Univ. Kastamonu Journal of Faculty of Education, 23(4), 1633-1646.

Quan, L. Y., Q1, C. H., \& Q1, S. S. (2015). The Correlation Of Video Games With Positive Affect And Negative Affect Among Utar (Perak Campus) Undergraduate Students, Research Project Submitted Inpartial Fulfillment Of The Requirements For The Bachelor Of Social Science (Hons) Psychology Faculty Of Arts And Social Science (Fas) University Tunku Abdul Rahma. Retrieved from http://eprints.utar.edu.my/2329/1/PY-2016-1203425.pdf

Saglam, M., Kayaduman, H., \& Delialioglu, O. (2016). Investigating the Parents Thoughts about the Effects of Digital Games on Children. In G. Chamblee \& L. Langub (Eds.), Proceedings of Society for Information Technology \& Teacher Education International Conference (pp. 605-610). Savannah, GA, United States: Association for the Advancement of Computing in Education (AACE). Retrieved 11 September, 2018 from https://www.learntechlib.org/primary/p/171740/

Savaş, S., \& Doruk, S. K. (2018). Research on Persuasion Dimension of The Archetypal Images and Usage Frequency of Archetypes In Turkish Advertisements. Galatasaray University. Journal of Communaciation, 28, 205-237. Https://doi.org/10.16878/gsuilet.436045

Say, S., \& Bağ, H. (2017).The Evaluation of the Effect of a Newly Designed Computer Game on 7th Grade Students' Motivation Towards Science and Aggression (2017). EURASIA Journal of Mathematics Science and Technology Education, ISSN: 1305-8223 (online) 1305-8215 (print) 2017, 13(8), 5379-5393.

Shi, J., Boak, A., ......Mann, R., et al. (2019). Adolescent Problem Video Gaming in Urban and Non-urban Regions. Int J Ment Health Addiction, 17, 817-827. https://doi.org/10.1007/s11469-018-9872-1

Şimşek, A. (1996). Educational Orientations in the Information Society. Kurgu Journal, 14, 241-247.

Temel, M., Kostak, M. A., \& Çelikkalp, Ü. (2014). Determination of Violence In Cartoon Movies Published In Children's Channels. DEUHYO ED 2014, 7(3), 199-205.

Temizyürek, F., \& Acar, Ü. (2014). The Impact of Subliminal Messages in Cartoons on Children. Cumhuriyet International Journal of Education-CIJE, 3(3), 25-39.

Tomczyk, L., \& Wąsiński, A. (2017). Parents in the Process of Educational Impact in the Area of the Use of New Media by Children and Teenagers in the Family Environment. Education and Science, 42(190), 305-323.

Torun, F., Akçay, A., Çoklar, A., \& Karaelmas, N. (2015). Analyzing of Computer Games Effects on Social Life and Academic Behaviour of The Secondary School Students. Journal of Educational Sciences, 3, 25-35.

Tosun, N., Geçer, A., \& ve Kaşıkc1, D. N. (2016). Examining the relationship between pre-service teachers' perceptions of internet ethics and locus of control. AUAd, 2(4), 82-103.

Tuncal, T., Yücel, D., Bal Tepe, N. B., Alııı Hoşgören, Y., Kırıcı, S., Baştuğ, G., \& Öel Kızıl, E. T. (2017). Expert opinions on the projection in caricatures of the view of aging. Elderly Issues Reszearch Journal (EIRJ), 10(1) 43-50.

Tutkun, Ö., Demirtaş, Z., Açıkgöz, T., \& Demirel Tekşal, S. (2017). The Effect Of Television And Digital Games On Secondary School Students' Tendency To Violence. PESA International Journal of Social Studies, 3(2), 83-91. 
Ulusoy, K. (2017). Opinions of History Teachers Related to Drug Addiction and Media Addiction. Kastomonu Journal of Education, 25(1), 385-400.

Van Deursen, Al. J. A. M., Bolle, C. L., Hegner, S. M., \& Kommers, P. A. M. (2015). Modeling habitual and addictive smartphone behavior, The role of smartphone usage types, emotional intelligence, social stress, self-regulation, age, and gender. Computers in Human Behavior, 45, 411-420.

Yeni, S. (2015). Examining The Effectiveness Of Educational Tablet PC Applicatıons to Teach Daily Living Skills to Students With Intellectual Disabilities. Unpublished PhD Dessertation in Computer Education and Instructional Technology Department, Middle East Technical University. Retrieved from http://etd.lib.metu.edu.tr/upload/12618908/index.pdf

Yetim, G., \& Sarıçam, H. (2016). Investigation of the Families' Knowledge and Awareness about Effect of Cartoon on Children. OPUS International Journal of Society Researches, 6(11), 341-364.

Yılmaz Genç, M. M., \& Fidan, A. (2017) Children, parents and tablets: Preschool children's tablet use. PEGEM Journal of Education and Teaching, 7(3), 367-398.

Zhitomirsky-Geffet, M., \& Blau, M. (2016). Cross-generational analysis of predictive factors of addictive behavior in smartphone usage. omputers in Human Behavior, 64, 682-693. https://doi.org/10.1016/j.chb.2016.07.061

2-Under the Theme of Central Exams And Private Courses; Reviewed Literature' Identification Related To Central Exams, Lecturers On Learning Variables, Education And How They Affect Students Negatively:

Aksoy, H. (2018). Education Expenses of Families. Pamukkale University Institute of Education Sciences (Unpyblished Master Thesis). Denizli. Retrieved from http://acikerisim.pau.edu.tr

Alkan, F., Acarlı, D. S., \& Altundağ, C. (2017). Teachers' Opinions towards Private Courses and Teachers' Efficacy. Çukurova University. Faculty of Education Journal, 46(2), 517-540. Retrieved from www.cufej.com

Arı, E., \& Yılmaz, V. (2015). Hopelessness Levels of Teachers Who Follow KPSS Preperation Courses. Gaziantep University Journal of Social Sciences, 14(4), 905-931.

Aslan, G. (2017). Determinants of Student Successes in Transition from Basic Education to Secondary Education (TEOG) Examination: An Analysis Related to NonSchool Variables. Education and Science, 42(190), 211-236.

Ataç, E. (2017). Reading Educational Inequalities in Turkey: Statistics and Geographic Distributions. Education and Science, 42(192), 59-86.

Ataç, E. (2017). Reading Educational Inequalities in Turkey: Statistics and Geographic Distributions. Education and Science, 42(192), 59-86.

Can, E. (2017). Determination Of The Effects Of Central Exams According To The View Of Students. The Journal of Academic Social Sciences, 5(58), 108-122. http://dx.doi.org/10.16992/ASOS.12842

Çetin, A., \& Ünsal, S. (2018). Social, Psychological Effects of Central Examinations on Teachers and Their Reflections on Teachers' Curriculum Implementations, Hacettepe University. Journal of Education. https://doi.org/10.16986/HUJE.2018040672

Ekinci, C. E. (2011). Impact of Some Socio-economic Factors on Higher Education Participation in Turkey. Education and Science, 36(160), 281-297.

Gürbüz, R., Erdem, E., Temurtaş, A., \& Koç, A. (2015). The Factors Affecting OSYS Achievement: The Case of Adiyaman. Adiyaman University Journal of Educational Sciences, 5(1), 49-71. https://doi.org/10.17984/adyuebd.52062

Karabay, E. (2014). Investigation of the Extra Scholastic Variables Explaining Students' Success on Placement Test via CHAID Analysis. Elementary Education Online, 13(2), 640-659.

Kumandaş, H., \& Kutlu, Ö. (2014). The Risk Factors Caused by Exams Used for Student Selection and Placement into Higher Education on the Academic Performance. Turkish Journal of Psychology, 29(74), 32-33.

Kumandaş, H., \& Kutlu, Ö. (2015). High stake tests. Journal of Educational Sciences Research, 5(2), 63-75.

Memduhoğlu, H. B., \& Kayan, M. F. (2017). Pre-Service Teachers' Perceptions of Selection and Assignment Regarding to Civil Servant Selection Examination (CSSE). YYU Journal Of Education Faculty, 14(1), 1259-1291. http://dx.doi.org/10.23891/efdyyu.2017.45 
Özcan, H. (2016). An Investigation On Factors Affecting Students' University Choice. AJELI - Anatolian Journal of Educational Leadership and Instruction, 4(1).

Özgen, N., Köşker, N., \& Yalçın, H. (2014). An analysis on private courses and its stakeholders in Turkey. Retrieved from https://www.academia.edu/23654191

Özgen, N., Köşker, N., \& Yalçın, H. (Winter 2015). Examining Of The Relation Between Private Courses and Geography Teaching: A Descriptıve Approach. Turkish Studies, 10(3), 713-732. http://dx.doi.org/10.7827/TurkishStudies.7721

Selmin, K. S., Kurucu, Y. Ş., \& Göktaş, S. (2018). The relationship between exam anxiety levels and sleep quality of senior high school students. Journal of Psychiatric Nursing, 9(2), 105-11. https://doi.org/10.14744/phd.2018.05025

Şimşek, H., \& Şimşek, S. (January 2015). Thinking Again The Study Center in Terms Of The Responsibility Of Family And Its Transformation. Kastamonu Journal of Education, 23(1), 365-384.

Yslmaz, M. B. (2017). The Impact Of Digital Assessment Tools On Students' Engagement in Class: A Case Of Two Different Secondary Schools. Abant İzet Baysal University Journal of Education Faculty, 17(3), 1606-1620. https://doi.org/10.17240/aibuefd.2017.17.31178-338850

Yılmaz, S., \& Bülbül, T. (2017). Evaluating the Reflections of High Stakes Tests on School Culture. Trakya University Journal of Education Faculty, 7(2), 578-617. https://doi.org/10.24315/trkefd.315491

3-Under the Theme of School, Education System And Education Practices; Reviewed Literature' Identification Related To Homework, Disconnection From Real Life, Discipline, Legislation And Procedures, Outdated Teaching Practices, Failure İn Classroom, Learning About Educational Fashion Variables, And How They Affect Students Negatively

Aksoy, H. (2017). Postponement Behavior in The Public Organization an Example Study At The Public Organization. Eskişehir Osmangazi University, Institude of Social Sciences, Department of Business Administration, Unpublished Master Thesis. Retrieved from http://openaccess.ogu.edu.tr/

Aliakbari, M., \& Hemmatiza, M. (2015). On Students' De-Motivation, Gender, Major, and Educational Level in Iranian EFL Context. English Language Teaching, 8(4), 106-116. https://do1.org/10.5539/elt.v8n4p106

Arseven, A. (2015). Mathematical Modelling Approach in Mathematics Education. Universal Journal of Educational Research, 3(12), 973-980. https://do1.org/10.13189/ujer.2015.031204

Arslan, Y., \& Polat, S. (2016). Intergenerational Conflict in Educational Organizations: Reasons and Coping Strategies. Ahi Evran University Kırşehir Journal of Faculty Education (KEFAD), 17(1), 263-282.

Balıkçı, A. (2016). Principalship in the Context of Daily Life and Bureaucracy. Eskişehir Osmangazi University, Educational Science Institude, Unpublished PhD Thesis. Retrieved from http://hdl.handle.net/11684/1346

Bektaş, M., \& Akdeniz Kudubeş, A. (2014). As a Measurement and Evaluation Tool: Written Exams. DEUHYO ED Dokuz Eylül University. School of Nursing Electronic Journal, 7(4), 330-336.

Ben-Shahar, T. H. (2016). Equality in Education-Why We Must Go All the Way. Ethic Theory Moral Prac, 19, 83-100. https://doi.org/10.1007/s10677-015-9587

Berkant, H. B., Efendioğlu, A., \& Sürmeli, Z. (2014). Investigatıon of Teachers' Views On Values Education. Turkish Studies, 9(5), 427-440.

Biesta, G. J. J. (2015). How does a competent teacher become good teacher? On judgement, wisdom and virtuosity in teaching and teacher education. In R. Heilbronn \& L. Foreman- Peck (Eds.), Philosophical perspectives on the future of teacher education (pp.3-22). Oxford: Wiley Blackwell.

Büyükoğlu, H. (2015). Examining the Flow Experiences of Principals in Schools. Eskişehir Osmangazi University, Educational Science Institude, Unpublished PhD Thesis. Retrieved from http://openaccess.ogu.edu.tr

Cai, M. (2017). A Study on Flipped Classroom-based Autonomous Learning Model Applied in English Visual-audio-oral Teaching. Advances in Social Science. Education and Humanities Research, 124, 314-318.

Can, N., \& Ermeydan, M., (2017). Teachers 'and administrators' views on disciplinary problems and classroom management. Kahramanmaraş Sütçü İmam University Journal of Education, 1(1), 38-57. 
Cerit, Y., Akgün, A., Yildız, K., \& Soysal, M. R. (2014). Problems and solutions for the processing of the application of the new schooling system $(4+4+4)$ (City of Bolu sample). Journal of Educational Sciences Research, 4(1), 59-82.

Çelebi, N., Övür, M., \& Eravc1, F. (2017). The Problems Faced By Provincial Educational Supervisors Working in The Investigation Group During The Process. Manisa Celal Bayar University Jurnal of Social Sciences, 5(1), 1-30. https://doi.org/10.18026/cbayarsos.298897

Demircioğlu, İ., \& Demircioğlu, E. (2016). What Do Turkish History Teachers Think About Edutainment. Kastamonu Education Journal, 24(3), 1301-1308.

Du, Y., \& Zhang, J. (2014). Education's Turn to Life World Under Globalization. Higher Education of Social Science, 6(1), 49-52. http://dx.doi.org/10.3968/j.hess.1927024020140601.Z011

Duru, S., \& Çöğmen, Ç. (2017). Views of Primary and Secondary School Students and Their Parents on Homework. Elementary Education Online, 16(1), 354-365. http://dx.doi.org/10.17051/io.2017.76577

Griswold, T. C. (2016). Best Practices in Second Language Teaching: A Holistic Doctrine Based on Research and Experience. All Graduate Plan B and other Reports, 774.

Erol, N. (2015). Managing Predominant Paradoxes in School Administration. Hacettepe University Educational Science Department, Unpublished PhD Thesis, Ankara. Retrieved from http://openaccess.hacettepe.edu.tr

Gezgin, E. (2016). Have you said "equal opportunity in education"?: To be a student in Çanakkale Fevzipaşa Neighbourhood. Journal of Human Sciences, 13(2), 2768-2792. https://doi.org/10.14687/jhs.v13i2.3872

Güneş, F. (2014). Homework Discussions in Education. Bartin University Journal of Faculty of Education, 3(2), 1-25. https://doi.org/10.14686/BUEFAD.201428169

Haug, P. (2017). Understanding inclusive education: ideals and reality. Scandinavian Journal Of Disability Research, 19(3), 206-217. http://dx.doi.org/10.1080/15017419.2016.1224778

Hanganu, E. (2015). Teaching Grammar In College. https://doi.org/10.13140/RG.2.1.2292.8806

Hidayah, S. N. (2016). Mentoring novice secondary teachers as an alternative training program: a case study of a secondary school in Indonesia. Doctor of Education thesis, School of Education, University of Wollongong. Retrieved from https://ro.uow.edu.au/theses/4939

Kılıç, Y. (2015). An Empirical Study on the Relationship between School Size and Discipline in Secondary Education in Turkey. Educational Administration Theory and Practice Journal, 21(1), https://doi.org/10.14527/kuey.2015.003

Durak, H. Y., \& Seferoğlu, S. S. (2017). Examination of Teachers' Sense of Burnout in Terms of Various Variables. GEFAD/GUJGEF, 37(2), 759-788.

Konstantinidou, E., Zisi, V., Katsarou, D., \& Michalopoulou, M. (2015). Barriers and Inhibitors of Creativity in Physical Education. European Psychomotricity Journal, 7(1), 17-31.

Korkealehto, K., \& Siklander, P. (2018). Enhancing engagement, enjoyment and learning experiences through gamification on an English course for health care students. International Journal Of Media Technology and Lifelong Learning, 14(1), 13-30.

Kuksina, O., \& Sokolova, N. (2014). Motivation and attitudes as the contributing factors in successful foreign language learning. Педагогіка, психологія і соиіологія (ISSN:2077-6780), 1(15), Ч.1

Küçüker, E. (2017). Transition between Grades and Development of Student Flow in Turkey, Ankara University. Journal of Faculty of Educational Sciences, 50(1), 43-97.

Kyriaki, M. (2017). Research in the field of inclusive education: time for a rethink? International Journal of Inclusive Education, 21(2), 146-159. https://doi.org/10.1080/13603116.2016.1223184

Lamanauskas, V. (2017). Reflections on Education. Šiauliai: Scientia Socialis Ltd, 244, ISBN 978-609-95513-3-3. Retrieved from https://www.academia.edu/41215035/REFLECTIONS_ON_EDUCATION

Launer, J. (2015). Resilience: for and against. Postgrad Med Joournal, 91, 721-722. https://doi.org/10.1136/postgradmedj-2015-133827

Lebedev, O. (2017). The End of Compulsory Education? Voprosy obrazovaniya / Educational Studies, Moscow(1), 230-259. https://doi.org/10.17323/1814-9545-2017-1-230-259 
Maharaj, C. M. (2017). Embodiment and the Boundaries Between Us in Virtual Reality. Malmö högskola/Kultur och samhälle, Master Thesis. Retrieved from http://hdl.handle.net/2043/23611

Matt, B., Cathie, H., Nerida, M. C., Austin, R., \& David, G. (2014). Augmented Reality in education-cases, places and potentials. Educational Media International, 51(1), 1-15. https://doi.org/10.1080/09523987.2014.889400

Met, Ö. (2016). Organizational Ombudsman Model As A Proactive Approach To Psychosocial Risks İn Working Life. Journal of Social Sciences, 49, 94-115.

Nugent, C. (2017). A multicase study of nature-kindergarten Practices: exploring three examples in Denmark. Finland and Scotland, $\mathrm{PhD}$ Thesis The University of Edinburgh, UK. Retrieved from http://hdl.handle.net/1842/25918

Özdemir, O., \& Erdemci, H. (2014). Vocational School Students' Opinions Towards Using Cloud Technology For Assignments. TURK-JES Turkish Journal of Educational Studies, 1(3), 145-165.

Öztürk, M. (2016). Induction Challenges Experienced by Novice Teachers Teaching in Villages and Small Towns. İlköğretim Online, 15(2), 378-390. https://doi.org/10.17051/io.2016.55573

Plessis, M. A. (2015). Clinical Legal Education Models: Recommended Assessment Regimes. PER / PELJ, 18(7), 2277-2802. http://dx.doi.org/10.4314/pelj.v18i7.11

Polat, S., Arslan, Y., \& Satıcı, Y. (2016). The Relationship between Teachers' Attitudes towards Teaching Profession and Classroom Discipline Model Preferences. GEFAD / GUJGEF, 36(3), 675-691.

Reno, R. R. (2020). The new new left. First Things: A Monthly Journal of Religion and Public Life, (246), 2014, p. 3+. Gale Academic OneFile, Accessed 14 July 2020.

Sadık, F., \& Öztürk, H. İ. (2018). Discipline at the school: Examination of school administrators' views about discipline and disciplinary problems. Pegem Journal of Education and Training, 8(4),729-770.

Sadık, F., \& Aslan, S. (2015). Investigation of Primary School Teachers' Views on Disciplinary Problems, Turkish Studies- International Periodical for the Languages. Literature and History of Turkish or Turkic Volume 10(3),115-138. http://dx.doi.org/10.7827/TurkishStudies.7585, Ankara-Turkey

Salama, A. M. (2014). 'Liveness' beyond design studio pedagogy: layers of 'live' within and across the boundaries of classroom settings. In: Proceedings of the 2nd Annual Conference of AAE-Association of Architectural Educators. AAE: Association of Architectural Educators, Sheffield, 88-93.

Şeref, İ., \& Varışoğlu, B. (2015). The Views About Turkish Subject Homeworks By Students Attending 7th And 8th Grade of Primary School. International Journal of Turkish Education Sciences, 2015, 93-105.

Tunç, B., Yıldız, S., \& Doğan, A. (2015). Discipline Problems in Vocational High School, Causes ind Solutions: A Case Study. Abant İzet Baysal University Journal of Faculty of Eduxcation Faculty, 15(2), 384-403.

Vansover, Y. (November, 2017). Creativity and Change. International Journal of Innovation, 3(2), 140-156.

Vatansever Bayraktar, H., \& Kaya, M. (2017). Okul yöneticilerinin okuldaki disiplin sorunlarıyla ilgili tutumlarının incelenmesi. Journal of Human Sciences, 14(1), 883-901. https://doi.org/10.14687/jhs.v14i1.4462

Uysal, İ. (2016). Problems Encountered by Students in Hosted Schools and Its Effects on Their Success. Pamukkale University, Institute of Educational Science, Unpublished Master Thesis, Denizli. Retrieved from http://acikerisim.pau.edu.tr:8080/xmlui/handle/11499/3290

Wirussawa, S., Tesaputa, K., \& Duangpaeng, A. (2016). An Effect of the Learning Environment Management System toward Student Quality of Thai Secondary School. International Education Studies, 9(5), 235-246.

Yorğun, A. (2014). Investigation Of School Drop Out Among Highschool Students. Hacettepe University, Educational Science Unpublished PhD Thesis, Ankara. Retrieved from http://www.openaccess.hacettepe.edu.tr

4-Under the Theme of Addiction; Reviewed Literature' Identification Related To Regarding Technology Addiction, Smoking-Alcohol-Drug Addiction Variables, and How They Affect Learning, And Students Negatively

Akkuş, D., Karaca, A., Konuk Şener, D., \& Ankaral, H. (January 2017). The Prevalence of Tobacco and Alcohol Use in High School Students and the Affecting Factors. Anatolian Clinic, 22(1), 36-45. 
Alaçam, H., Çulha Ateşci, F., Şengül, C., \& Tümkaya, S. (2015). The relationship between smoking and alcohol use and internet addiction among the university students. Anatolian Journal of Psychiatry, 16(6), 383-388.

Emekdar, G., Çıtıl, R., Önder, Y., Bulut, Y. E., Yaşayancan, Ö., Kazancı, N. Ö., Sönmezgöz, E., \& Eğri, M. (2017). Smoking Prevalence and Related Factors Among Secondary and High School Students in Tokat Province. Journal of Contemporary Medicine, 7(1), 1-8. https://doi.org/10.16899/gopctd.286207

Erdamar, G., \& Kurupınar, A. (2014). The Habit of Drug Addiction and Prevalence Among the Secondary School Students: Sample of Bartın City. Journal of Social Sciences, 16(1), 65-84. https://doi.org/10.5578/JSS.7521

Erdem, H., Türen, U., \& Kalkın, G. (2017). No Mobile Phone Phobia (Nomophobia) Prevalence: Samples of Undergraduate Students and Public Employees from Turkey. Journal of Information Technologies, 10(1), 1-12. https://doi.org/10.17671/btd.30223

Koç, P., \& Albayrak, M. (2017). Farklı Gelişim Düzeylerindeki Bireyler Üzerinde Internet bağımlılığının Etkileri. Suleyman Demirel University The Journal of Faculty of Economics and Administrative Sciences, 22(Special Issue on Kayfor15), 2391-2404.

Özay Köse, E., Gül, Ş., \& Keskin, B. (2017). The Examination of Secondary School Students' Awareness and Knowledge Levels about Substance Addiction. Journal of Dependence, 18(1), 8-15.

Savci, M., \& Aysan, F. (2017). Technological addictions and social connectedness: predictor effect of internet addiction, social media addiction, digital game addiction and smartphone addiction on social connectedness. The Journal of Psychiatry and Neurological Sciences, 30, 202-216. https://doi.org/org/10.5350/DAJPN2017300304

Ulusoy, K. (2017). Opinions of History Teachers Related to Drug Addiction and Media Addiction. Kastamonu Journal of Education, 25(1), 385-400. R

Yılmazsoy, B., \& Kahraman, M. (2017). Addiction To Social Media And Usage Of The Social Media For Educational Purposes: The Facebook Example. Journal of Instructional Technologies \& Teacher Education, $6(1), 9-20$.

5-Under the Theme of Health; Reviewed Literature' Identification Related to Excessive Consumption Culture, Unhealthy Nutrition Variables, Learning and How They Affect Students Negatively

Ahraz, S. (2017). The Determination of High School Students's Feeding Profile and The Factors Affecting It, Selçuk University. Health Sciences Institute Unpublihed Master Thesis, Konya.

Aksoy, M. (2017). Student, teacher, administrator and parent opinions on school canteens, Pamukkale University educational Science Institute. Unpublished Master Thesis, Denizli. Retrieved from http://acikerisim.pau.edu.tr

Aktaş, N., \& Özdoğan, Y. (2016). Food and Nutrition Literacy. Harran Journal of Agricultural and Food Sciences, 20(2), 146-153. https://doi.org/10.29050/harranziraat.259105

Altınc1, E. E., Keskin, B., Türksoy, A., Güvendi, B., \& Doğan, B. (2016). Investigation of Nutritional Behaviors and Sports Activity Situations in Istanbul Province Bayrampaşa Uluğbey Primary School 7th and 8th Grade Students. İsrtanbul University Journal of Sport Sciences, 6(4), 17-27.

Arıkan, İ., Yavuz, B., Yiğit, D., \& Ece, E. (2017). Investigation of Risky Behaviors and Some Sociodemographic Factors in University Students: Sample From a State University. Contemporary Medicine Journal, 7(4), 348-354. https://doi.org/10.16899/gopctd.290382

Ayyıldı, Y., \& Demirli, Y. (2015). Public Opinions in Obesity Tax: A Field Research in Turkey. Business and Economics Research Journal, 6(2), 59-78.

Balcı Çelik, S., Vural Batık, M., Özcan, K., \& Aksoy, S. (Winter 2015). The Attitude toward Obese Children Scale: A Study of Validity and Reliability. e-International Journal of Educational Research, 6(1), 40-53. https://doi.org/10.19160/e-ijer.94465

Başta, M. (2016). Interpersonal Communication in the Process of Psychological Harassment in Postmodern Societies. Selçuk University, Social Sciences Institute Unpublished Master Thesis, Konya. Retrieved from http://hdl.handle.net/123456789/4014 
Bebiş, H., Akpunar, D., Özdemir, S., \& Kılıç, S. (2015). Assessment of health promotion behavior of adolescents in a high school. Gulhane Medical Journal, Gulhane Military Medical Academy, 57, 129-135. https://doi.org/10.5455/gulhane.43275

Boğa, Ö., \& Başc1, A. (2016). Word Of Mouth Marketing in Health Care Organizations And A Pilot Study. Marmara University Journal of Suggestion, 12(45), 463-489. https://oi.org/10.14783/od.v12i45.1000020022

Dal, N., \& Dal, V. (2016). A Theoretical Study About The Role of The Television Advertisements and Family in The Process of Socialization of Children as Consumer. Mehmet Akif Ersoy University Journal of Social Sciences Institute, 1(13), 371-388.

Dil, S., Gönen Şentürk, S., \& Aykanat Girgin, B. (2015). Relationship between risky health behaviors and some demographic characteristics of adolescents' self-esteem and healthy lifestyle behaviors in Çankırı. Anatolian Journal of Psychiatry, 16, 51-59.

Doğan, A., Uğurlu, C. T., \& Çetinkaya, M. (Yaz 2015). Obesity's Repercussions On Educational Processes According To The Teachers' Opinions. Electronic Journal of Social Sciences, 14(54), 173-191.

Emlek Sert, Z., \& Bayık Temel, A (2017). Investigation of Factors Associated With Weight Management in Primary School Students. DEUHFED Dokuz Eylul University Faculty of Nursing Electronic, 10(1), 13-21.

Erdoğan, E. G. (2016). The relationship of body mass indexs in high school students with socio demographic and nutritional characteristics. International Journal of Human Sciences, 14(2), 1571-1589.

Ezmeci, F., Çoban Söylemez, E. T., Akgül, E., \& ve Akman, B. (2017). The Analysis of Advertisements Give Place to Children inTerms of Messages Given to Children and Adults, Roles and SexBased Discrimination Components. Galatasaray University Journal of Communaciation, 26, 247-279. https://doi.org/10.1678/gsuilet.324859.

Gönül, T. (2018). The Effect of Media on Family Expenses and the Importance of the Family's Economic Function. Istanbul Commerce University Institute of Social Sciences Unpublished Mastes Thesis, İstanbul. Retrieved from http://library.ticaret.edu.tr/e-kaynak/tez/75748.pdf

Hilal Yayan, E., \& Çelebioğlu, A. (2018). Obesogenic Environment and Effects on Childhood Obesity. ACU Journal of Health Sciences, 9(2), 90-96. https://doi.org/10.31067/0.2018.12

İkikat Tümer, E. (2015). Healthy Nutrition and Traditional Foods. Journal of Tourism and Gastronomy Studies 3(1), 55-63. https://doi.org/10.18016/ksudobil.348267

İkikat Tümer, E. (2018). Fast Food Consumption Decisions of High School and Equivalent School Students. KSÜ Journal of Agriculture and Nature, 21(1), 1-6. https://doi.org/10.18016/ksudobil.348267.

İskender, M., Tura, G., Akgül, Ö., \& Turtulla, S. (2014). The relationship between the family environment, eating behavior and obesity for the secondary school students. International Journal of Human Sciences, 11(2), 10-26. https://doi.org/10.14687/ijhs.v11i2.2940

Kahraman, Ç. (2018). Nutrition Habits and Obesity Risk in University Students: The Case of Tekirdă̆ Namık Kemal University. Nam1k Kemal University Institute of Social Sciences Department of Health Management Unpublished Master's Thesis, Tekirdağ. Retrieved from http://hdl.handle.net/20.500.11776/2937

Kartal, F. (2017). Assessment of Relationship between Usage of Media Resources such as Television, Computer/Video Game and Food Consumption in Adolescents. Hacettepe University Institute of Medical Sciences. Dietetic Program, Master Thesis, Ankara. Retrieved from http://www.openaccess.hacettepe.edu.tr/

Karakaş, H., \& Törnük, F. (2016). An Investigation on Role of Traditonal Foods on Nutrition of School Age Children, Cumhuriyet University Faculty of Science. Science Journal (CSJ), 37(3), 292-302.

Mammadova, M. (2015). Unıversıty Youth And Consumptıon Trends: Selcuk Unıversıty Example, Selçuk University. Social Sciences Institute Unpublished Master Thesis, Konya. Retrieved from http://acikerisimarsiv.selcuk.edu.tr

Meltem Kürtüncü, M., Uzun, M., \& Ayoğlu, F. N. (2015). The Effect of Adolescent Training Program on Risky Health Behaviours and Health Perception. Journal of Higher Education and Science, 5(2), 187-195. https://doi.org/10.5961/jhes.2015.121

Ocak, S., Kılıçaslan, Ö., Yıldırmak, Z. Y., \& Urgancı, N. (2017). Adolescents and anemia. The Medical Bulletin of Sisli Etfal Hospital, 51(4), 309-317. https://doi.org/10.5350/SEMB.20170927094446

Onurlubaş, E., Doğan, H. G., \& Demirkıran, S. (2015). Diatery Habits of College Student, Gaziosmanpaşa 
University. Journal of the Faculty of Agriculture JAFAG, 32(3), 61-69. https://doi.org/10.13002/jafag861

Öz, F. (2015). Evaluation of the Effectiveness of Internet Based Nutrition Education Programme in adolescents: A Randomized Controlled Trial. Eskisehir Osmangazi University Medicine of Faculty. Department of Public Health, Medical Speciality Thesis, Eskisehir. Retrieved from http://openaccess.ogu.edu.tr

Özilbeya, P., \& Ergör, G. (2015). Determining the prevalence of obesity in primary school students and eating habits in Izmir. Turk J Public Health, 13(1), 30-39. https://doi.org/10.20518/thsd.45885

Savaşhan, Ç., Sarı, O., Aydoğan, Ü., \& Erdal, M. (2015). Obesity frequency in school children and related risk factors. Turkish Journal of Family Practice, 19(1), 2-9. https://doi.org/10.15511/tahd.15.01014

Soylu, T. (Şubat 2017). Determination of Sugar and Sugar-containing Food Consumption and Obesity Status of Children Attending Preschool Education Institutions in Kırıkkale. Doğu Akdeniz University Unpublished Master Thesis, Gazimağusa, Kuzey Kıbrıs. Retrieved from http://i-rep.emu.edu.tr

Toktaş, N., Erman, A. K., \& Yetik, O. (2018). Healthy Lifestyle Behaviors And Physical Activity Levels Of Male University Students According To Human Chronotype. Abant Izzet Baysal University Journal of Faculty of Education, 18(1), 507-520.

Tözün, M., Sözmen, M. K., \& Babaolu, A. B. (2017). Association of Dietary Habits With Obesity, Physical Activity and Quality Of Life in Health Related Faculties Of A University in West Turkey. Estudam Public Health Journal, 2(1), 1-16.

Taşdelen, B. (2016). Daily life on the role of consumer cases investigating in the child magazine in terms of gender. Gümüşhane University Faculty of Communication Electronic Journal, e-gifter, 4(2), 806-816. https://doi.org/10.19145/gujofoc.04790

Uzdil, Z. (2017). The Relationship between Eating Attitudes and Eating Habits, Anthropometry and Demographic Characteristics in High School Students. Düzce University Journal of Health Sciences Institute, 7(1), 11-18.

Yıldırım Aksakal, B., \& Oğuzöncül, A. F. (2017). An Examination of Obesity Frequency and Its Affecting Factors of the Students of High Schools in the Elazig City Center. Dicle Medical Journal, 44(1), 13-23. https://doi.org/10.5798/dicletip.298575

Yıldırım, S., Uskun, E., \& Kurnaz, M. (2017). Associatıon Between High School Students' Body Images And Eating Attıtudes. International Anatolia Academic Online Journal Health Sciences, 4(2), 1-12.

Yüksel, E., Adıyaman, F., Keçeli, D., Doruk, Ö., Yavuz, Ö., \& Kasdemir, B. (2014). How The Issue Of Obesity Framed in The Press? Selçuk Üniv. Journal of Communaciation, 8(2), 149-176.

Zembat, R., Kılıç, Z., Ünlüer, E., Çobanoğlu, A., Usbaş, H., \& Bardak, M. (2015). The Place of Preschool Education Institutions in Child's Acquisition of Nutrition Habits. Hacettepe University Faculty of Health Sciences Journal. Retrieved from https://dergipark.org.tr/tr/pub/husbfd/issue/7893/103905

6-Under the theme of the Environment; Reviewed Literature' Identification Related to Violence, Swearing and Using Slang, Bullying, Moral Collapse, Noise Pollution, Ignoring Others, Chitchatting Variables, and How They Negatively Affect Education and Students

Can, N., \& Ermeydan, M. (2017). Teacher and administrator views on disciplinary problems and classroom management. Kahramanmaraş Sütçüimam University Journal of Faculty of Education, 1(1), 38-58.

Dağtaş, E. (2011). An Evaluation On The Communication Education in Turkey From The Perspective of University-Industry Cooperation. Akdeniz University Journal of Communication Faculty, 15, 32-48.

Hasan, T., Murat, T., \& Furkan, A. (2017). Investigation of Secondary School Students' Cyberbullying in terms of Various Variables. Online Journal of Technology Addiction \& Cyberbullyin, 4(1), 41-59.

Emin Ahmet, K., \& Melike Rana, D. (2017). A Burden on Economy. Terror The Journal of International Social Research,10(49), 623-636.

Ersin, D., \& Birgül, T. (2017). What Would Happen Without Social Media? A Qualitatıve Research On Social Media Addicted Youngsters' Opınıns. International Peer-Reviewed Journal Of Communication and Humanities Research UHIVE, 17, 89-206. Https://doi.org/10.17361/UHIVE.2017.4.17

Güçlü, M. (2015). Studies Conducted On Values Education in Turkey. Atatürk High Institution of Culture, Seekıng 
A Better Future In Educatıon: Internatıonal Symposium On Educatıon Of Skılls, Morals And Values In Turkey From The Past To The Present. Language and History, Atatürk Research Center Publications, 29-58.

Kasap, F., Mırçık, A., \& Dolunay, A. (2018). Reproduction of Violence in the Media: A Review on Turkey's Main News Bulletins. Journal of History Culture and Art Research, 7(1), 684-699. http://dx.doi.org/10.7596/taksad.v7i1.1414

Kocadaş, B. (2005). Culture and Media. Bilig Bilig, 34, 1-13.

Levent, C. (2017). A Research on the Consumer Perception of Ethics by Advertisements Penalized for Violation of the Article of the Ad Board titled "Advertisements for Children". Doğuş University Social Science Institute, Unpublished Master Thesis, İsatnbul. Retrieved from https://openaccess.dogus.edu.tr

Nagehan, Y. (2015). Symbolic Violence on Social Media: Example Of Ekşi Sözlük. Pamukkale University Institute of Social Sciences Unpublished Master Thesis, Denizli. Retrieved from cikerisim.pau.edu.tr/

Nevin, P. (2006). The Effect of Visual Media and the Culture of Violence on Secondary School Students. Selçuk University, Health Science Institute, Unpublished Master Thesis. Retrieved from http://acikerisimarsiv.selcuk.edu.tr/

Ömer, Ö. (2017). The Use of Violence in Media: Economics of Violence, the Ideological Violence of Media and an Evaluation in Retrospect of Cultivation Theory. Marmara Journal of Communication, 27, 1-19.

Özlem, B., \& Bertan, A. (2016). School Security According to The Views of School Principals and Teachers in Primary Schools (Aydın Efeler Sample), Adnan Menderes University. Journal of Institute of Social Sciences, 4(1), 74-95.

Tellan, D. (2011). Context Of Public Relations Education Communication, Social Sciences or Manufacturing Consent. Journal of Akdeniz University Communication Faculty, 15, 11-31.

Ünver, H., \& Koç, Z. (2017). The Investigation of The Relationship among Cyber Bullying, Problematic Internet Use and Risky Internet Behaviors. Turkish Journal of Educational Sciences, 15(2), 117-140.

\section{Copyrights}

Copyright for this article is retained by the author(s), with first publication rights granted to the journal.

This is an open-access article distributed under the terms and conditions of the Creative Commons Attribution license (http://creativecommons.org/licenses/by/4.0/). 